University of Louisville

ThinkIR: The University of Louisville's Institutional Repository

Electronic Theses and Dissertations

$5-2013$

\title{
"Tis a consummation devoutly to be wished" : mortality, sexuality and spirituality in the early modern period.
}

Whitney L. Brown

University of Louisville

Follow this and additional works at: https://ir.library.louisville.edu/etd

\section{Recommended Citation}

Brown, Whitney L., "'Tis a consummation devoutly to be wished" : mortality, sexuality and spirituality in the early modern period." (2013). Electronic Theses and Dissertations. Paper 165.

https://doi.org/10.18297/etd/165

This Master's Thesis is brought to you for free and open access by ThinkIR: The University of Louisville's Institutional Repository. It has been accepted for inclusion in Electronic Theses and Dissertations by an authorized administrator of ThinkIR: The University of Louisville's Institutional Repository. This title appears here courtesy of the author, who has retained all other copyrights. For more information, please contact thinkir@louisville.edu. 
"TIS A CONSUMMATION DEVOUTLY TO BE WISHED": MORTALITY, SEXUALITY AND SPIRITUALITY IN THE EARLY MODERN PERIOD

\author{
By \\ Whitney L. Brown \\ B.A., Centre College, 2011
}

\begin{abstract}
A Thesis
Submitted to the Faculty of the

College of Arts and Sciences of the University of Louisville in Partial Fulfillment of the Requirements

for the Degree of
\end{abstract}

Master of Arts

Department of English

University of Louisville

Louisville, Kentucky

May 2013 
Copyright 2013 by Whitney L. Brown

All rights reserved 

"TIS A CONSUMMATION DEVOUTLY TO BE WISHED": MORTALITY SEXUALITY AND SPIRITUALITY IN THE EARLY MODERN PERIOD

\author{
By \\ Whitney L. Brown \\ B.A., Centre College, 2011
}

A Thesis Approved on

April 16, 2013

by the following Thesis Committee:

\begin{tabular}{c} 
Matthew Biberman \\
Thesis Director, English \\
\hline Hristomir Stanev \\
English \\
\hline Genevieve Carlton \\
History
\end{tabular}




\section{DEDICATION}

This thesis is dedicated to my parents, Rev. Arnold Brown and Mrs. Melissa Brown, who have given me their constant love and support throughout my academic career and before it. Thank you so much. I love you both. 


\section{ACKNOWLEDGEMENTS}

I would like to acknowledge the contributions to this thesis by my committee members, Drs. Matthew Biberman, Hristomir Stanev and Genevieve Carlton. I would not have been able to finish this, my best work, without their support, advice and participation. I would also like to thank Dr. Dale Billingsley for formulating the assignment that would become the seeds of this thesis in the Fall of 2011. Finally, I would like to thank Drs. Bronwyn Williams and James Romesburg for their guidance over the course of my time here at the University of Louisville, and Drs. Mark Rasmussen, Phillip White, Patrick Kagan-Moore, Tony Haigh, and Prof. Matthew Hallock for their guidance during my studies at Centre College. This thesis is truly the culmination of many years of academic investigation, and I believe that each of these professors is, in some fashion, responsible for my growth as a scholar. Thank you all. 


\title{
ABSTRACT \\ “TIS A CONSUMMATION DEVOUTLY TO BE WISHED”: MORTALITY, SEXUALITY AND SPIRITUALITY IN THE EARLY MODERN PERIOD
}

\author{
Whitney Brown
}

April 16, 2013

This thesis explores the eroticism of mortality and spirituality during the Early Modern Period. This thesis argues that this eroticism stems from anxiety about the loss of human control to the forces of Death and the Divine. This led writers and artists to frame mortality in terms of the limit-experience of sexuality. By characterizing death as an intimate relationship with a personified figure, Early Modern artists could explore mortality's hold over humanity, as well as humanity's ability to choose mortality willingly. Mortality was also intricately linked to the religious fervor of the Early Modern Period, as believers sought to eroticize their spiritual relationships with the only being they considered more powerful than Death, their God. This relationship with God allowed believers to transcend the boundaries of finitude and cross into infinitude. This thesis identifies tropes associated with this impulse and provides a survey of key sources involved in their exploration. 
TABLE OF CONTENTS

PAGE

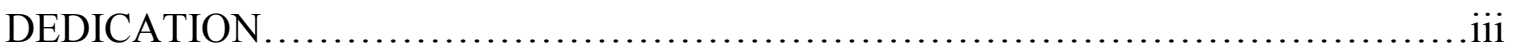

ACKNOWLEDGEMENTS.........................................................

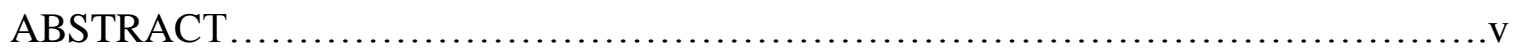

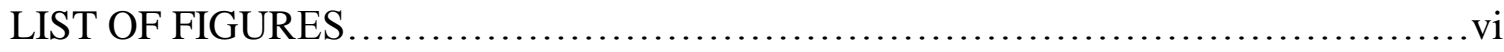

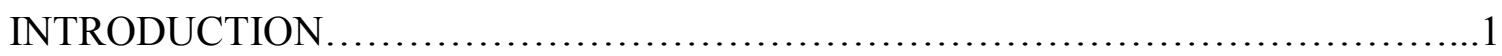

CHAPTER I: AMOROUS MORTALITY ...........................................

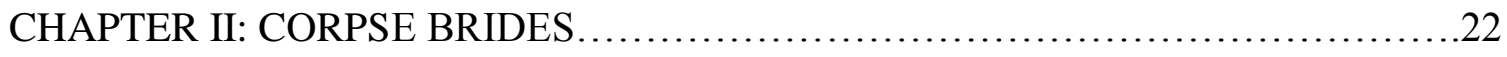

CHAPTER III: DEADLY PROPOSALS ......................................... 31

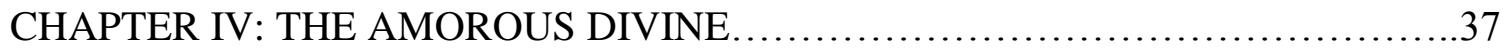

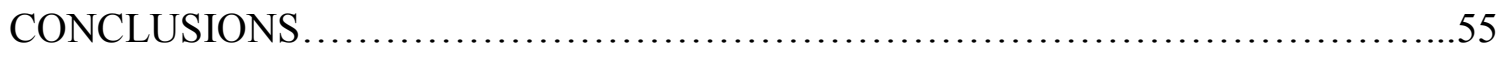

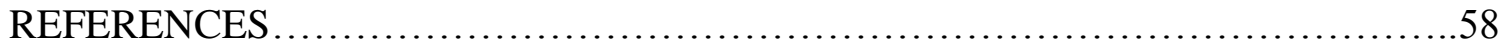

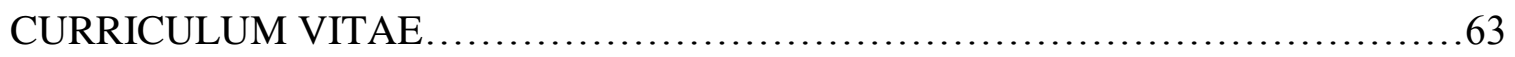




\section{LIST OF FIGURES}

FIGURE PAGE

1. Bern Dance of Death by Niklaus Manuel...................................6

2. Dance of Death, XXIV. The Nun by Hans Holbein the Younger..................7

3. Dance of Death, XXXVI. The Duchess by Hans Holbein the Younger..............7

4. Three Ages of the Woman and Death by Hans Baldung Grien...................9

5. Death and the Maiden by Hans Baldung Grien $(1515) \ldots \ldots \ldots \ldots \ldots \ldots \ldots \ldots$

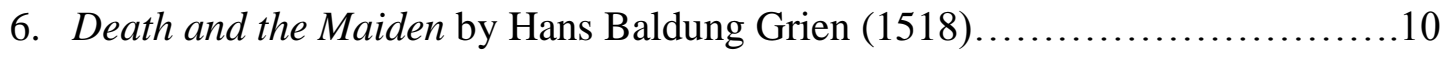

7. Copy of the Effigy on the tomb of Eleanor of Castile by William Torel...........13

8. Ophelia by Sir John Everett Millais......................................33

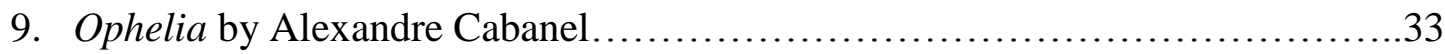

10. 4th Century A.D. Roman Sarcophagus Panel................................40

11. 3rd Century Roman Sarcophagus......................................40

12. The Ecstasy of St. Teresa by Gian Lorenzo Bernini..........................46

13. Details of the Ecstasy of St. Teresa by Gian Lorenzo Bernini....................46 


\section{INTRODUCTION}

Michel Foucault notes that "at the beginning of the seventeenth century a certain frankness [about sex] was still common...Codes regulating the coarse, the obscene, and the indecent were quite lax" (An Introduction, 3). Foucault explains that sexual repression began with the nineteenth century, which was preoccupied with erecting barriers hiding sexuality from view and acknowledging only "a single locus of sexuality...the parents' bedroom" (An Introduction, 3). However, in pre-Capitalist Europe, sex was allowed to be an acknowledged aspect of every part of life. Foucault claims that "Sexual practices had little need of secrecy; words were said without undue reticence, and things were done without too much concealment" (An Introduction, 3).

This lack of sexual barriers was evident even in discussions of mortality. Throughout the Early Modern Period, mortality and sexuality were uncomfortable bedfellows. Often appearing as a pair, these seeming opposites kept close company in much of the English literature generated before the Restoration. Mortality is often personified as either a legitimate husband, or an illegitimate lover, coming to claim his bride or mistress while his living rivals look on, admiring the corpse bride while lamenting their powerlessness in the face of Mortality's irresistible advances. However, the living, finally, invert this relationship by accepting Mortality themselves. Rather than passively accepting their thralldom, they rush into the arms of Mortality, claiming death as their own. 
In more practical terms, life and death were intertwined in Ancient and Medieval medical theory. Coles points out that, according to Aristotle (whose views on biology remained popular throughout the Middle Ages and the Renaissance), semen originated as blood, the "liquid nutriment of the body" (Coles 48). It seemed only natural to Aristotle that the creation of life must result in the shedding of this life-sustaining liquid. However, as Guibbory notes, it was believed that, because a man emitted his life's blood in his semen, sexual intercourse could shorten his life ("Erotic Poetry," 145). Therefore, mortality was literally a part of the sexual experience, and this physical "fact" was bound to influence the realm of ideas. It is widely known that "to die" became a popular euphemism for achieving orgasm in the Early Modern Period. Rambuss identifies one poem that will be discussed in this thesis, "Batter my heart, three-person'd God" by John Donne as a limit-experience for the speaker (59). This concept, which is found in the works of such theorists as Foucault, Bataille and Blanchot, identifies the experience of meeting the extreme edge of life in a way that transcends ordinary reality. It is possible that "to die" became a euphemism for orgasm because of this concept. While the concept was not coined until the twentieth century, sex was understood to be a transcendent experience, as was death. Sex approaches the very limit of physical intimacy and pleasure, ending in exhaustion, while death is the limit of known existence. They are both symbols of finitude. The intense and extreme nature of both sexuality and mortality allowed the Early Modern Period, with its openness about allowing sexuality into even the unlikeliest of places, to discuss the finite nature of death, that "undiscovered country" through the more comprehensible experience of sex (Hamlet 3.1.80). 
The secularism of modern society has given death the potency of a true limit, of true finitude, in the popular mind. However, no such limit existed in the Early Modern Period. Spirituality, particularly the Christian belief in Heaven and the Resurrection of the Saints, was a great comfort when facing mortality due to its emphasis on the eternal nature of the soul. The Holy Trinity, Heaven, and the soul are all images of infinitude that defy death. Thus, the connection between mortality and spirituality is obvious because they are essentially opposed, yet, immortality is not possible (for a human being) without having first experienced mortality. However, the connection between sexuality and spirituality throughout the Early Modern Period is puzzling, even when one considers the prevalence of sexual content in the culture of the time. Religious statutes attempting to regulate sexual practices would seem the most likely intersection between sexuality and spirituality, but there is another, more direct way in which sexuality and spirituality were partnered. Sexuality became a lens through which many writers and artists filtered spiritual devotion. Spirituality was its own limit-experience, an experience in which the mortal experienced the divine. Sex, another powerful limit-experience, allowed Early Modern thinkers to express the bewildering limit-experience of spirituality with the more tangible limit-experience of sexuality, just as sex assisted them in understanding death. The ecstasy of sex, though finite, was an effective, if imperfect, metaphor for the infinite union with God. In this way, mortality, sexuality, and spirituality were inextricably linked in the Early Modern mind.

Another aspect of the discussion that cannot be ignored is the legal implications that crop up at every turn. As previously mentioned, Mortality is often cast as a lover or a husband. These relationships define the sexuality in question as legal or illegal. It was 
understood during the Early Modern Period that sexuality was bound up in rights of inheritance and the legal ownership of a woman's body. In this relationship, Mortality owns everyone, including the young women whom he comes to court. The living may either accept this passively or actively, but they must accept it somehow. Yet, spirituality complicates this idea, for God, ultimately, controls even Death. If Death seems inescapable, he is nothing compared to God. Thus, Death's legal claim to everyone is disrupted.

The following thesis identifies four major tropes in Early Modern literature, Amorous Mortality, the Corpse Bride, Deadly Proposals, and the Amorous Divine. Amorous Mortality is characterized by personified figures of death, often insubstantial and ghostly, or in form of skeletons. The Corpse Bride is the generally passive counterpart to Amorous Mortality; she is usually a deceased female who remains an object of desire, despite the transgressive nature of this impulse. Deadly Proposals refer to those instances in which the living court Mortality themselves, rather than anticipate Mortality's eventual victory. Finally, the Amorous Divine is characterized by divine beings who seek the affections of mortals.

This thesis serves primarily as a survey of key sources for these tropes, as well as a few interesting variations intended to demonstrate the complexity of these tropes within the Early Modern Period. While this survey is in the style of the work of the New Critics, it makes overtures towards New Historicism. This thesis does attempt to propose some tentative conclusions, but its principal goal is to identify tropes that have rarely been discussed in Early Modern scholarship and spearhead this conversation. 


\section{CHAPTER I}

\section{AMOROUS MORTALITY}

Before moving on to the literature of the Early Modern Period, it is important to establish the Ancient foundation that will influence any understanding of the way these tropes play out in Early Modern literature. The Tudor and Elizabethan Periods saw the blossoming of the Renaissance in England. The Renaissance was, in many ways, a synthesis of Ancient and Medieval world views. It combined Greco-Roman philosophy and literature with Medieval Christianity. Thus, a short discussion of how Ancient and Medieval thinkers treated these tropes should prove fruitful.

Mortality is personified in Classical mythology as Dis, or Pluto, the god of the Underworld, who falls in love with Proserpine, the goddess of springtime. According to Ovid, Pluto abducts Proserpine as she is out picking flowers, carrying her off to the land of the dead. Her mother, Ceres, goddess of the harvest, roams the world, mourning for her lost daughter, allowing the fields, and the humans who depend on them, to wither and die. She finally goes to Jove, or Jupiter/Zeus, Proserpine's father, who is both the king and the supreme arbiter of the gods. Ceres begs that Proserpine be returned to her, but Jove answers that this abduction is "not spight, but love" on Dis' part (V.653). Besides, he and Ceres should not feel "ashamed" to have Dis as a son-in-law, since he is Jove's own brother (V.654-7). However, Jove adds, if Ceres is so eager for Proserpine's return, Proserpine may do so on the condition that "she have tasted there no food," for it is an 
irrevocable law that whoever has eaten in the Underworld must remain there (V.662). Of course, Proserpine has spent a great deal of time in the Underworld so, despite her knowledge of this law, she has eaten a few pomegranate seeds, and Jove allows her to return from the Underworld for part of the year. She remains Dis' wife, and death is married to springtime. For this reason, the ancients say, the winter comes when Proserpine leaves her mother and returns to her husband.

This trope appears again in Medieval Europe in pieces of artwork depicting the Danse Macabre, or the Dance of Death. This common motif was intended to spread the concept of

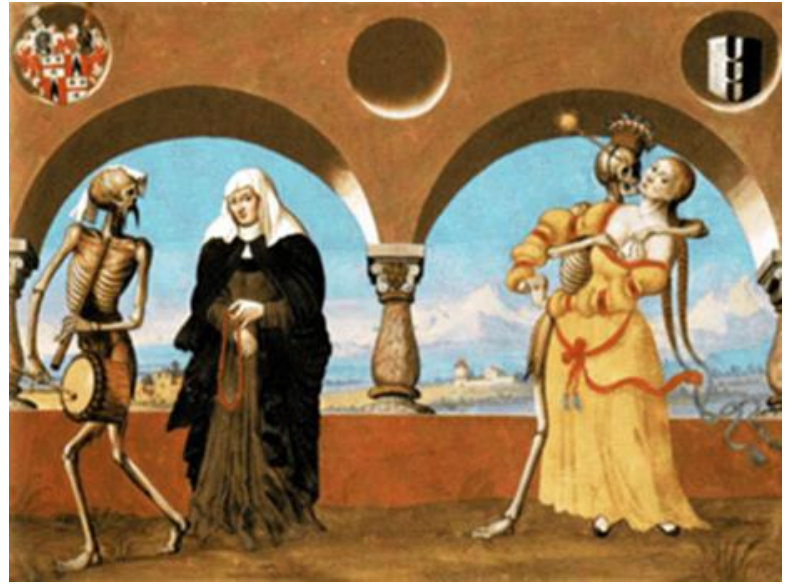

Figure 1 Bern Dance of Death by Niklaus Manuel, ca. 1516-1520. Bern. death as the great equalizer, taking rich and poor, young and old, indiscriminately. Many of these pieces contained personified figures of Mortality paying overtures to beautiful, young women. As Binski notes, dancing was a considered "sensual" and was "tied closely with music associated with seduction" (Binski 155). It is not surprising that artists assumed the death figures would pay court to the prettiest girls in the paintings once the music started, but the image can be surprisingly sexual. Kurtz notes that Niklaus Manuel painted a version of the Dance of Death in Bern, Switzerland on the wall of a church that was once a Dominican cloister (Kurtz 114). While most of this structure was destroyed and vast portions of the painting with it, some fragments remain, including a fragment consisting of a skeleton groping a young lady's bosom while possibly whispering sweet nothings in her ear (Fig. 1). The 
lady in question gives no indication that she either welcomes or resents this treatment. Rather, she looks out of the painting at the viewer with an expressionless face and a passive stance, as if she merely accepts the skeleton's right to do as he pleases.

Hans Holbein the Younger, a favored portrait artist in the court of Henry VIII, made a series of woodcuts depicting the Dance of Death between 1522 and 1526 (Kurtz 190-2). Two of these woodcuts seem particularly lascivious (Fig. 2 and 3).

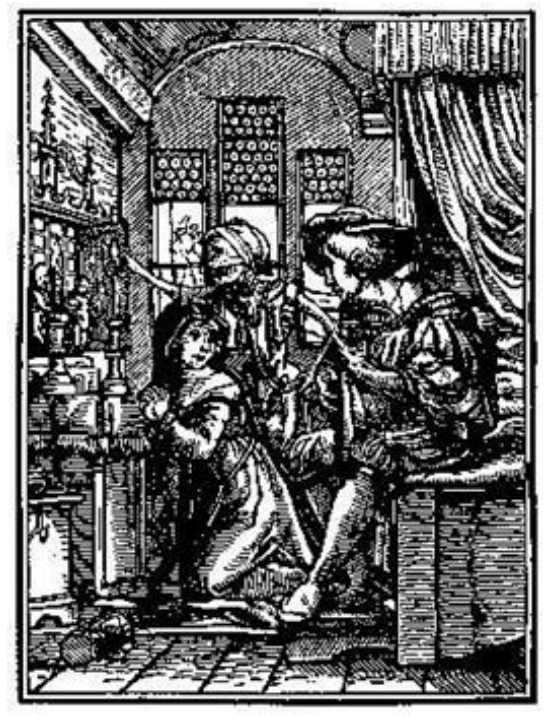

Figure 2 Dance of Death, XXIV. The Nun by Hans Holbein the Younger, ca. 1522-1526.

Fig. 2 depicts a nun who has allowed a man to enter her room while a skeleton reaches out to snuff her candle. She is kneeling at an altar, hands clasped in prayer, while her suitor sits on her bed, strumming a lute. The nun's face is turned away from the altar, her mind focused on the flesh, rather than the spirit. Mortality, in the form of the skeleton does not play the role of amorous lover in this scenario, but he encourages and facilitates the illicit encounter, nonetheless. Fig. 3 depicts a noblewoman in bed.

Figure 3 Dance of Death, XXXVI. The Duchess by Hans Holbein the Younger, ca. 1522-1526.

Two skeletons stand at the foot of the bed, one playing a violin, while the other appears to be climbing into bed to join her. This is, no doubt, intended to show that Death comes to all, including the rich and powerful. However,

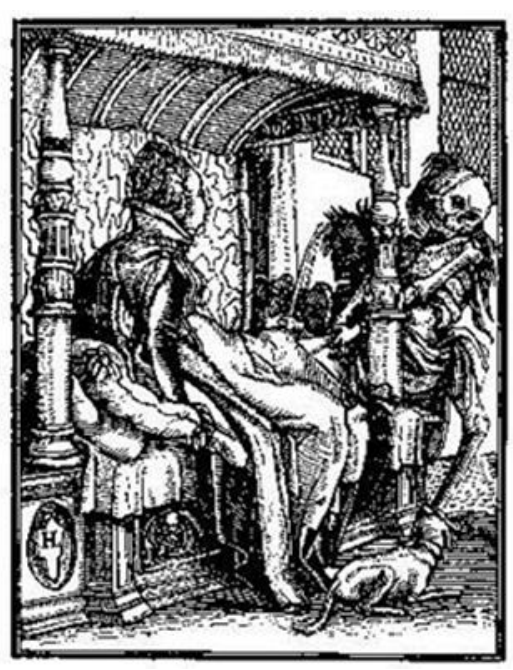


the erotic positioning of the figures is somewhat puzzling. In both Holbein woodcuts, music underscores the dance motif, but it also provides a romantic edge to each scenario. The fact that each scene takes place in the privacy of the bedroom adds to the erotic charge, since it is clear that the beds are likely to be full momentarily. While this Dance of Death raged through the visual art world, courts across Europe were developing "highly organized social dance[s]" that exhibited the dancers' ability to conform to civilized society (Binksi 155-6). These court dances were highly structured and depended on strict adherence to the rules of artistry. The Dance was, therefore, the ideal medium to display one of the laws of God, the inevitability of Mortality, but these particular examples seem to violate those laws, as well, given that Mortality and his maidens make such odd couples.

The Danse Macabre motif, with its figures of Amorous Mortality, branched off to the Death and the Maiden motif. The most important artist of this motif was Hans Baldung Grien (ca. 1484-1545), a German artist who was a student of Albrecht Dürer. According to Marrow and Shestack, Baldung became particularly concerned with the topic of "gruesome death" between 1509 and 1512 (Baldung, 9) ${ }^{1}$. Many of Baldung's works appear to be expressions of "anxiety in the face of the forces of nature" (Baldung, 9). For instance, Fig. 4, often referred to as The Three Ages of Woman and Death, depicts a baby girl tangled up in the veil of her sexually mature counterpart, who is admiring herself in a mirror. Meanwhile, Death holds onto the other end of the veil while holding an hourglass above the young woman's head.

\footnotetext{
${ }^{1}$ All of the works of art by Hans Baldung Grien discussed in this paper can be found in Hans Baldung Grien: Prints and Drawings: National Gallery of Art, Washington, from January 25 through April 5 and Yale University Art Gallery, New Haven, April 23 through June 14, 1981: Exhibition edited by James H. Marrow and Alan Shestack. However, I was unable to make acceptable photocopies of these works, so I was forced to seek them from other sources.
} 


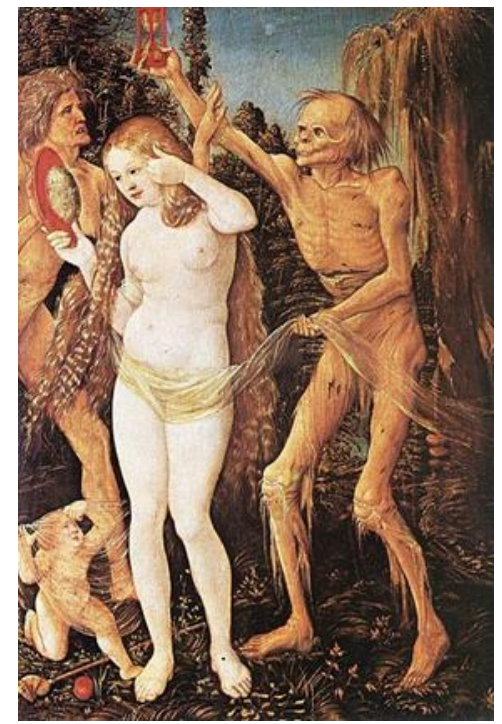

Figure 4 Three Ages of the Woman and Death by Hans Baldung Grien, ca. 1510. Kunsthistorisches Museum, Vienna.
An older woman attempts to move Death's arm away from the young woman, but Death cannot be swayed. As Marrow and Shestack note, the "presence of the three generations emphasizes the message of inevitable aging and death" (Baldung, 9). Yet, there may be more to this grouping than meets the eye. Death threatens all three females, but it is noteworthy that his attention is reserved entirely for the young, beautiful, fair-skinned and sexually available woman. It would, perhaps, make just as much

sense for him to threaten the older woman, who is, no doubt, closer to the grave than the other two. Meanwhile, the threat of infant death could have made this a poignant work indeed, if Baldung had chosen to bring Death closer to the child, given the high infant mortality rates characteristic of the Early Modern Period. However, Death (and the viewer) is drawn to the young woman, who is the true image of vitality and potential for life in this piece.

Fig. 5, also by Baldung and drawn approximately five years after The Three Ages of Woman and Death, shows Death and the Maiden in similar poses, but it moves away from anxiety about decay and towards a more sexualized anxiety.

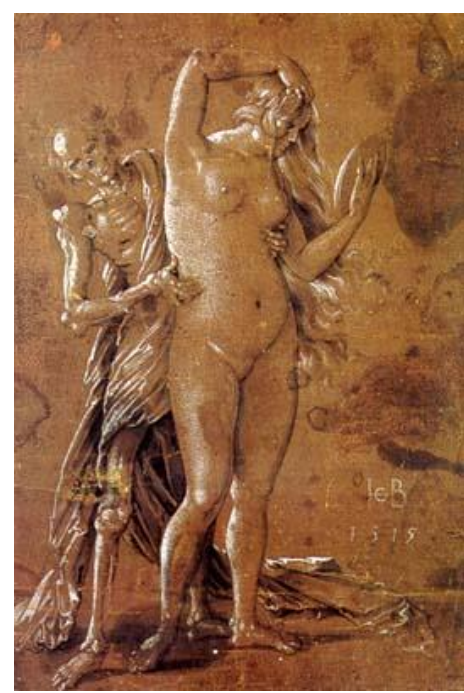

Figure 5 Death and the Maiden by Hans Baldung Grien, 1515. Staatliche Museen, Berlin. The Maiden is admiring herself in a mirror and pulling back her hair, just like the Maiden 


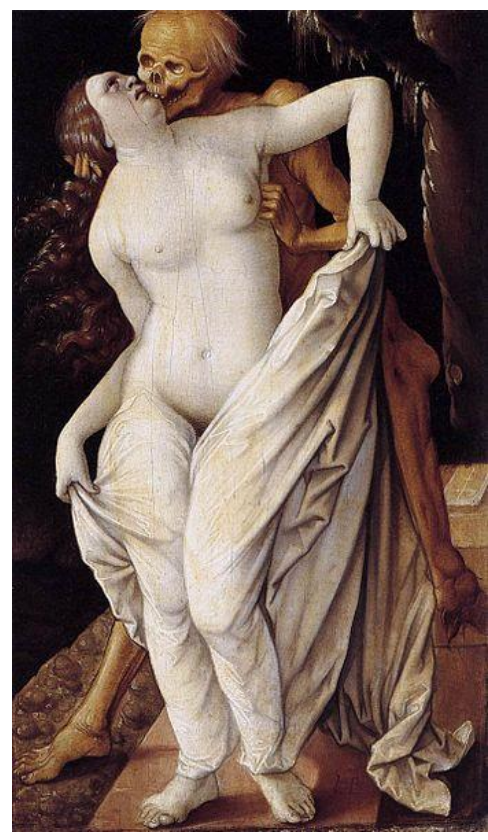

Figure 6 Death and the Maiden by Hans Baldung Grien, ca. 1518. Kunsthistoriches Museum, Basel.

of The Three Ages of Woman and Death, but she and Death are alone with no chaperon to speak of. Furthermore, Death has one hand on her waist and another just below her left breast, which are rather intimate places for him to leave his hands. Fig. 6, also by Baldung and painted even later than the other two, moves even farther away from the message of decay and goes straight into a rape scenario. The Maiden has no mirror, but she clutches at her covering, as if she is trying to protect herself from exposure, while Death touches her and kisses her face. While the other two maidens seem unaware of Death's nearness, the maiden of Fig. 6 appears to be both terrified and disgusted by his attentions.

In these examples of the Amorous Mortality trope, barren Death is juxtaposed with vital fertility, and each example carries legal implications. In Ovid's Metamorphoses, Jove, Proserpine's guardian and legal arbiter of the gods, recognizes Death's right to Life, in the forms of Dis and Proserpine, respectively. In the Dance of Death tradition, individuals from all walks of life eventually belong in Death's embrace, including pretty young girls. In a bizarre twist, Death also insists that his victims and objects of affection should dance a parodic version of the art form they have created to express their civilized acceptance of the rules of society.

John Donne takes the Amorous Mortality trope in a rather unexpected direction in "The Apparition." Donne creates a speaker who imagines a future in which his ghost haunts the uncooperative object of his affections. He says, "When by thy scorn, O 
murd'ress, I am dead...Then shall my ghost come to thy bed"2(1-4). The speaker claims that he will find this "feign'd vestal" in "worse arms" than his (5). If the beloved attempts to seek comfort from her new lover, he will "shrink" from her, leaving her abandoned to her fears (7-10). The speaker says, "thou / Bath'd in a cold, quicksilver sweat wilt lie, / A verier ghost than I" (11-13). The bed is, of course, a proverbial and, in this case, literal place of sexual union, from which the spectral speaker has been barred and where the beloved will dally with another lover. This deathly figure proves that the beloved is not "free" from his "solicitation," as she had hoped (2-3). The ghostly lover will seek out his beloved even in death. While the speaker makes no overtly sexual claims on the beloved, his assertion that she will be a "verier ghost" than him implies a sort of symbolic procreation. Just as sexual union is expected to result in offspring, the ghost is able to beget another ghost in his beloved ${ }^{3}$. Furthermore, the speaker predicts that his beloved will bathe in a "quicksilver sweat" (12). Quicksilver, or mercury, was a common treatment for sufferers of syphilis, which was known to be transmitted through sexual contact. Syphilis was, of course, generally fatal, and the treatment was just as dangerous as the infection. The speaker's phrasing here is rather difficult to unpack. He may mean that she will be so frightened by his ghostly presence that her agitation, evidenced by her sweat, will be as deadly as a syphilis treatment. Or, he may mean to imply that her second lover will infect her, and she will have to deal with the consequences of a syphilis treatment, which would, no doubt, involve sweating out the quicksilver. In this way, the beloved's promiscuity may be responsible for her death

\footnotetext{
${ }^{2}$ It should also be noted that Donne rhymes "dead" and "bed." This unity of sound implies unity of meaning. Therefore, the bed becomes a place for the dead, and death becomes a place for bedding.

${ }^{3}$ The sexual union of the beloved and her new lover appears to be sterile. No mention is made of any desire or expectation of children. This is somewhat ironic. The traditionally fertile sexual act is made sterile, but the traditionally sterile state of death is made fertile. Death manages to appropriate, along with everything else, the traditional procreative power of sex.
} 
quite literally, just as the speaker, her former lover, wishes to drive her to an early grave with his hauntings.

Amorous Mortality's fatal desire for pretty women occasionally follows the victims right into their graves. "Methought I saw the grave where Laura lay," by Sir Walter Ralegh is an ambiguous example of the Amorous Mortality trope in poetry that would become so much a part of the literature of the Early Modern Period. The speaker describes a vision he has had of the grave of Laura, the idealized object of desire in Petrarch's sonnets. The theme of this sonnet is the poetry of Edmund Spenser, whose epic poem The Faerie Queene, is seen to eclipse the fame of Petrarch, as the Fairy Queen herself arrives and takes "fair Love and fairer Virtue" away with her (5-7). While Laura is hardly the focus, the sonnet's treatment of her is complex. This poem primarily praises her for her chastity, noting that her grave is "Within the temple where the vestal flame / Was wont to burn," a reference to Vesta, the Roman goddess of the hearth whose priestesses were called the Vestal Virgins because of their vows of celibacy (2-3). However, there is one line that complicates this: "Oblivion laid him down on Laura's hearse" (10). It is, admittedly, something of a stretch, but it is possible to read into these lines a sexual implication. The word lay had the connotation "to deposit in the grave" by the eleventh century, and it was already beginning to take on sexual overtones as early as the mid-fourteenth century ("Lay, v.1”). Furthermore, by placing Laura's grave in the temple of the Vestal Virgins, Ralegh may be referencing the Early Modern practice of interring socially important individuals in churches (Binksi 57). Many of these tombs included effigies depicting the deceased laid out on a bed, as if they were merely sleeping or in a pose suggesting life, as in Fig. 7. 
This practice is referenced by John Webster in The Duchess of Malfi. The Duchess, who does not realize that Bosola is about to murder her, attempts to jest with him about tombs after he says he is a "tombmaker" (4.2.130). He says:

Princes' images on their tombs do not lie, as they were won't, seeming to pray up to heaven, but with their hands under their cheeks, as if they died of the toothache. They are not carved with their eyes fixed on the stars, but as their minds were wholly bent

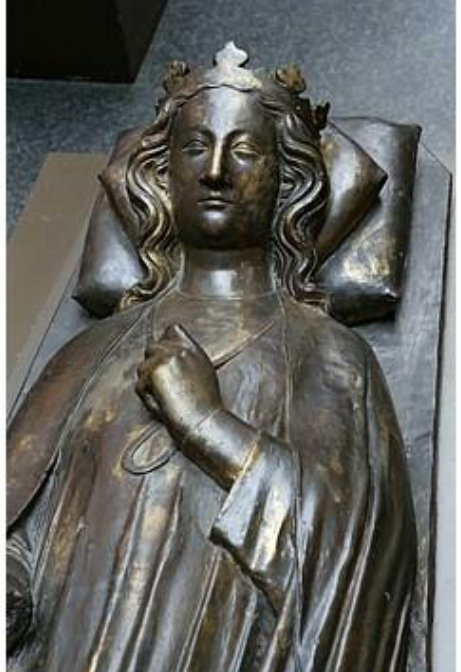

Figure 7 Copy of Effigy in the tomb of Eleanor of Castile by William Torel, ca. 1290. $V \&$ A Museum, London. upon the world, the selfsame way they seem to turn their faces. (4.2.137-41)

Bosola chides the important figures of the Renaissance for ignoring the religious nature of Medieval effigies in order to create life-like, worldly images of themselves in death. If it was Ralegh's intention to remind the reader of these worldly, life-like, secular effigies, the scene also carries with it the erotic connotation of a woman lying in her bed as the Death-like figure of Oblivion lies down on top of Laura's grave and likeness.

The Duchess of Malfi allows Bosola, a human being, to stand in as a death figure. In an unusual twist, Bosola is also a surrogate for the Duchess' brother Ferdinand. The Duchess is a young widow who has drawn the attention of many suitors, as well as the attention of her brother. Ferdinand is uncomfortably obsessed with his sister's sexuality. The first hint of this comes when Ferdinand hires Bosola to live in the Duchess' court, and "note all the particulars of her 'havior, / What suitors do solicit her for marriage, / And whom she best affects" (1.2.159-61). In the absence of their late father and the Duchess' late husband, Ferdinand takes it upon himself, as the Duchess' closest male 
relative, to safeguard her honor. However, he notes that "She's a young widow: / I would not have her marry again" (1.2.161-2). Bosola questions Ferdinand's wish, but Ferdinand simply says, "Do not ask me the reason, but be satisfied / I say I would not" (1.2.163-4). Ferdinand later claims that his sole motive was that "I had a hope, / Had she continued widow, to have gained / An infinite mass of treasure by her death," but there is a great deal of evidence throughout the play that his motive was not so much greed for wealth, but incestuous jealousy of his sister's affections for another man (4.2.260-2).

For instance, Ferdinand and their brother the Cardinal address the Duchess concerning the issue of her availability. While the Cardinal's language remains restrained, Ferdinand's language is intemperate. They say:

CARDINAL: We are to part from you, and your own discretion Must now be your director.

FERDINAND: You are a widow:

You know already what man is; and therefore

Let not youth, high promotion, eloquence-

CARDINAL: No, nor any thing without the addition, honor, Sway your high blood.

FERDINAND: Marry! They are most luxurious

Will wed twice. (1.3.1-8, emphasis mine)

While the Cardinal focuses on their sister's honor and discretion, Ferdinand is wholly concerned with her previous sexual experience as the wife of the Duke of Malfi, as well as the possibility that she could be so lustful as to have sexual relations, even marital and licit relations, with another man. When it comes to light that the Duchess may have given birth to an illegitimate child, Ferdinand is furious. He receives the news in a letter which he calls a "mandrake" he has dug up and which has driven him "mad" (2.5.1-2). He shows this letter to the Cardinal as evidence that their sister has "Grown a notorious strumpet" (2.5.4). He imagines that the Duchess "had most cunning bawds to serve her 
turn, / And more secure conveyances for lust / Than towns of garrison for service" (2.5.911). Ferdinand's description of the letter as a mandrake is telling. The mandrake was a root said to have both magical and medicinal properties. The mandrake root grows in a forked shape resembling the legs of a human, and it was said that if a mandrake was pulled out of the ground, it would shriek until the person harvesting it died or was driven mad, a belief Shakespeare references in Romeo and Juliet, when Juliet is contemplating the drug given to her by Friar Laurence $(4.4 .46$, fn. 2$)$. In medical terms, the mandrake was valued as both an aphrodisiac and a poison (The Duchess of Malfi $2.5 \mathrm{fn}$. 1). This metaphor is highly applicable because this letter shrieks to Ferdinand that his sister is "damned" for her lack of chastity, and it poisons his mind against her. However, it may also indicate that his sister's lusty nature fills him with incestuous desire, as evidenced by his fevered imaginings that she employs bawds to find men who can appease her sexual appetite. Ferdinand goes a step further by admitting that his "imagination will carry me / To see her in the shameful act of sin...with some strong-thighed bargeman...or else some lovely squire / that carries coal up to her privy lodgings" (2.5.40-6). The rumor that the Duchess has had sexual relations with another man gives Ferdinand vivid and voyeuristic fantasies about his sister's sexual activities, as well as the idealized men she may have taken as her lover.

Ferdinand goes on to imagine the cruel and violent revenge he would take on the Duchess, her lover, and their child:

I would have their bodies Burnt in a coal pit with the ventage stopped, That their cursed smoke might not ascend to heaven; Or dip their sheets they line in in pitch or sulphur, Wrap them in 't, and then light them like a match; Or else to boil their bastard to a cullis, 
And give ' $t$ to his lecherous father to renew

The sin of his back. (2.5.67-74).

This unaccountably vengeful reaction comes to a head when Ferdinand instructs Bosola to strangle the Duchess to death. Bosola goes to the Duchess dressed like an old man, calling himself a tombmaker. Bosola brings in some executioners who are carrying the Duchess' coffin, the ropes with which they will strangle her, and the bell that will affirm her death sentence. Bosola's costume is, perhaps, reminiscent of the robes or tattered clothing often worn by Death figures in art, as in Fig. 5. In this case, Bosola, the harbinger of mortality, is not amorous for the Duchess, but he is also a surrogate for her brother, who has her executed because of a "marriage, / That drew a stream of gall quite through [his] heart," due to his incestuous jealousy (4.2.263-4). In this scene, Mortality, Bosola, and the lustful Ferdinand are all conflated to achieve a murder that is, at its heart, the rape of a desirable woman.

In Shakespeare's Romeo and Juliet, Capulet, Juliet's father, takes up the Amorous Mortality trope after finding Juliet comatose from Friar Laurence's drugs on the day chosen for her bigamous marriage to Paris. Capulet is highly concerned with the act of giving his daughter in marriage. Earlier in the play, after Juliet had been informed by her mother that Paris would be ready to make her a "joyful bride" on "next Thursday morn" at Saint Peter's Church thanks to the machinations of Juliet's "careful father" (3.5.10715). Juliet declares that "He shall not make me there a joyful bride," which leads her mother to introduce what would become a steady theme throughout the rest of the play. Juliet's mother tells her husband, “Ay, sir, but she will have none, she gives you thanks. / I would the fool were married to her grave" (3.5.139-40). To say that Capulet does not take Juliet's refusal well would be a gross understatement. Capulet threatens to "drag 
thee on a hurdle thither," meaning that he will take her through the streets to her wedding on the same type of "sledge used to draw traitors through the streets to execution," (3.5.155, fn. 8). When that does not elicit the desired response, Capulet threatens to disown her and banish her from his presence. If she does not marry Paris, he says that she will "never after look me in the face," and she may "Graze where you will, you shall not house with me" (3.5.161-88). Capulet says, "An you be mine, I'll give you to my friend. / An you be not, hang, beg, starve, die in the streets, / For by my soul, I'll ne'er acknowledge thee" (3.5.191-3, emphasis mine). Capulet clearly considers his position as father to be one of ownership of his daughter. She legally belongs to him, and he may dispose of her as he wishes, either by giving her to the husband of his choice, or by throwing her out of her home and letting her fend for herself.

However, Capulet's claim on Juliet is threatened by Mortality's claim over everything. Capulet laments to his intended son-in-law that he, Paris, has been cuckolded and robbed by Death:

O son, the night before thy wedding day Hath death lain with thy wife. See, there she lies, Flower as she was, deflowerèd by him. Death is my son-in-law, death is my heir. My daughter he hath wedded. I will die, And leave him all. Life, living, all is death's. (4.4.62-7, emphasis mine).

This is an odd piece of imagery because a father is imagining and mourning his daughter's abduction and rape by Death, much as Ceres mourned the rape of Proserpine. Capulet may have the story of Prosperine in mind, since he calls Juliet a "Flower," which identifies her with the goddess of springtime, who was picking flowers on the day of her abduction. Capulet's language is strangely invasive as he discusses his daughter's 
deflowering, or loss of virginity, by this powerful and irrepressible suitor ${ }^{4}$. Then, in a strange rhetorical move, Capulet switches to the legal implications of Juliet's union with Death, as Jove does in Ovid's Metamorphoses. Death becomes Capulet's son-in-law and heir. Rather than a rapist, he becomes Juliet's legitimate, though metaphorical, husband. Capulet chooses to recognize Death's right to Juliet, since all belongs to Death, including her. With no living son-in-law, Capulet has no one to whom he can leave his wealth ${ }^{5}$. As in the Danse Macabre, everything that Capulet has belongs to Death: his daughter, his fortune and, soon, his own life.

The image of Amorous Mortality is invoked again by Romeo in the final scene of the play. He enters Juliet's tomb, kills Paris and addresses the sleeping Juliet:

Ah, dear Juliet,

Why art thou yet so fair? Shall I believe

That unsubstantial death is amorous,

And that the lean abhorrèd monster keeps

Thee here in dark to be his paramour? (5.3.101-5, emphasis mine)

Wells identifies this particular Death figure as originating in tales of the "incubus," a sexually ravenous demon that comes to women in their sleep (917). Death, which has "sucked the honey of [Juliet's] breath," has retained her still-beautiful body as the object of his lust (5.3.92). Death is now an "abhorrèd monster" who is holding the fair damsel captive in his lair. Furthermore, she is his "paramour." This term does not just carry sexual implications, but legal ones, as well. A "paramour" is not only a lover, but she is often an "illicit or clandestine lover or mistress, esp. taking the place of a husband or wife; (now Sc. Law and U.S. Law) the person with whom a married man or woman has an

\footnotetext{
${ }^{4}$ This imagery may also have shades of the same uncomfortable possessiveness as Ferdinand's absorption with his sister.

${ }^{5}$ This may be related to the Classical association between Pluto and wealth, given Pluto's nature as a chthonic god ruling over all the minerals and precious objects mined from the earth.
} 
adulterous relationship" ("Paramour," n. 3). This must be a particularly painful subject for Romeo, who was (technically, still is) Juliet's lawful husband and how has lost her to a more powerful rival. It is really Romeo who is being cuckolded, not Paris. This is, perhaps, an even more insidious image than that conjured up by Capulet, since Romeo dwells upon Death's unnatural, "unsubstantial” form, and his illicit attentions.

In light of this scene, Juliet's earlier words at the end of the first act seem almost prophetic. As Romeo is leaving the masquerade at the home of the Capulets, Juliet asks her Nurse to get the name of the mysterious young man who wooed her moments before. Once the Nurse is gone, Juliet says, "If he be marrièd, / My grave is like to be my wedding bed" (1.5.131-3). The wedding bed is a traditional scene of sexual union, the place where the bride will, theoretically, lose her virginity. Here, Juliet equates this tradition with the grave, as if, should Romeo prove unavailable, she will take Death as her husband, instead. She makes a similar statement later on after she learns of Romeo's exile. She says, "I'll to my wedding bed, / And death, not Romeo, take my maidenhead" (3.2.136-7). Death is invoked in a less direct sense in the final scene of the play when Paris visits Juliet's grave. Paris says, "Sweet flower, with flowers thy bridal bed I strew" (5.3.12). Flowers, symbols of fertility, have been used in wedding rites for centuries up to and including the present. Paris performs this "true love's rite" for his intended bride. There is a defeated quality about this act, as if Paris is surrendering to his rival, Death, and is preparing her for her wedding with him. There is a similar scene in Hamlet during Ophelia's funeral. Gertrude strews flowers upon Ophelia's grave, just as Paris does for Juliet. As she does this, Gertrude says:

Sweets to the sweet. Farewell. I hoped thou shouldst be my Hamlet's wife. 
I thought thy bride-bed to have decked, sweet maid, Not to have strewed thy grave. (5.1.221-4).

Death is, once again, invoked in a marital and, therefore, sexual moment.

The Amorous Mortality trope serves one primary function: it conflates the limitexperiences of sex and death. The Rape of Proserpine depicts Mortality, in the form of Dis, taking his new wife/victim, a fertility goddess, to the limit of earthly experience by physically crossing the boundary between Life and Death. The Underworld is, literally, under the world, and going beneath the surface of the earth symbolically brings Proserpine to marry Mortality. Meanwhile, the Danse Macabre and Death and the Maiden motifs confront mortals with other figures of Amorous Mortality who court them before taking them to their deaths. Similarly, plays like Romeo and Juliet and the Duchess of Malfi conflate the limit-experiences of sex and death by replacing sex with death. Juliet would experience sex by either marrying Paris or living with Romeo, but when these two situations are impossible, either because her marriage to Paris would be a sin or because Romeo has committed suicide, then embracing Amorous Mortality is considered an appropriate alternative. Meanwhile, Ferdinand would like to share the limit-experience of sex with his sister, but this, too, proves impossible, and he simply replaces that with the experience of having her murdered. In each case, the expenditure of energy in orgasm is equated with the snuffing of the candle in the Nun's bedroom in Fig. 2, which is, incidentally, an image used by Shakespeare in Macbeth when Macbeth describes the death of his wife (Macbeth 5.5.22). In all of these examples, the audience is presented with the image of finitude, death, taking ownership of the images of life. 


\section{CHAPTER II}

\section{CORPSE BRIDES}

Romeo's attention to Juliet's (supposed) corpse points to a variation on this Amorous Mortality trope - the Corpse Bride, in which the living male desires the dead female, or the dead female desires the living male. The audience is aware that Juliet is not, in fact, a corpse. However, her new husband, Romeo, is still reeling from the news that she has died of grief. Yet, Romeo does not respond to Juliet's body as if he is viewing a corpse. Rather, he views her prone form with the attitude of a lover admiring his beloved:

Death, that hath sucked the honey of thy breath,

Hath had no power yet upon thy beauty.

Thou art not conquered. Beauty's ensign yet

Is crimson in thy lips and in thy cheeks,

And death's pale flag is not advancèd there. (5.3.92-6)

Notice the attention to the "crimson" of her "lips" and "cheeks." These are clues to Juliet's true vitality, and the audience may wish for Romeo to read them correctly, thereby avoiding his despairing suicide, but he does not. In his mind, Juliet is dead, but her body continues to register for him as an erotic object. Romeo soon acts on this erotic impulse by taking advantage of her crimson lips, once before drinking the poison he has acquired, and once afterwards. The first time he kisses her, he "seal[s] with a righteous kiss / A dateless bargain to engrossing death" (5.3.114-5). His language here takes on the 
now-familiar legalese. Making a "bargain" with Death could be similar to the marriage Capulet has already described, or it could be an extension of Capulet's declaration that he will leave everything to Death - in this case, Romeo could be bowing to his victorious rival. Whatever the case may be, Romeo makes his own union with Death by swallowing poison. He is now, effectively, a dead man talking, and when he says, "Thus with a kiss I die," and kisses her for the last time, he is an essentially dead body kissing what he thinks is another dead body.

Similarly, Ophelia's grave is a rich site for sexuality. Graves themselves have already shown themselves to contain the potential for sexual imagery in the form of lying down in or on a sort of bed. However, the grave also carries vaginal imagery. A corpse may be seen to return to Mother Earth in a reverse birthing process, or, as in the case of Ophelia's funeral, it may have much more violent connotations. As the grave diggers begin to cover Ophelia's corpse with dirt, Laertes, who takes almost as much interest in his sister's virtue as Ferdinand from The Duchess of Malfi, declares, "Hold off awhile, / Till I have caught her once more in my arms" $(5.1 .227-8)^{6}$. Laertes jumps into the grave and embraces his sister's body and says, "Now pile your dust upon the quick and the dead / Till of this flat a mountain you have made, / T'oertop old Pelion or the skyish head / Of blue Olympus" (5.1.229). Laertes is soon followed by Hamlet, who fights him for her body, saying:

I loved Ophelia. Forty thousand brothers

Could not with all their quantity of love

Make up my sum...

Dost come here to whine,

To outface me with leaping in her grave?

Be buried quick with her, and so will I.

And if thou prate of mountains, let them throw

\footnotetext{
${ }^{6}$ For examples of Laertes' rather uncomfortable brotherly love, see Hamlet 1.3.5ff.
} 
Millions of acres on us till our ground,

Singeing his pate against the burning zone,

Make Ossa like a wart! Nay, an thou'lt mouth,

I'll rant as well as thou. (5.1.249-64)

The most apparent use of the Corpse Bride trope is the attention being paid to Ophelia's corpse, now decked in Gertrude's flowers, by her erstwhile suitor and her brother, his standing rival for court favor and, possibly, Ophelia's affections. Their shared desire to be buried alive with her, laying in the grave with her corpse, has erotic undertones. However, this scene may take a step towards the symbolic. If the grave is vaginal in nature, then one does not simply have to accept that it is Mother Earth's. One may take a cue from the Gravedigger in taking logic to its extreme in deciding who or what owns this grave (5.1.104-25). In this case, the vaginal grave belongs to Ophelia, and it represents her more literal vaginal opening. Thus, when her brother and suitor leap into her grave, it is just as much a metaphorical rape as it is a desecration of a grave.

Surrey's "Wyatt resteth here, that quick could never rest" is a rather unusual example of a poetic genre known as a blason, as well as an interesting variation on the Corpse Bride trope. Poems of this type list the various parts of a particular human body from head to toe, usually with the intention of using the exterior, physical body to characterize the interior, ephemeral soul. Other examples include Edmund Spenser's "Sonnet 64" and William Shakespeare's "Sonnet 130." Surrey makes the rather interesting choice to compose a blason upon a corpse, the body of his friend Sir Thomas Wyatt the Elder. The casual reader of this poem may not see the sexuality at work here, but one familiar with this genre recognizes a tension between the subject and the genre. The subject of a blason is usually, as is the case in the sonnets by Spenser and Shakespeare, the speaker's living beloved. The act of dwelling so conspicuously on 
another body has an erotic nature that does not agree with the speaker's relationship to his subject, a dead man. This eroticism is mitigated by the use of fairly non-erotic body parts, such as a "head where wisdom mysteries did frame," or a "visage stern and mild" $(5,9)$. Meanwhile, a few body parts have erotic potential, but are hardly erotic in context, such as a "hand that taught what might be said in rhyme," a "tongue that served in foreign realms his king," an "eye whose judgment none affect could blind," or a "heart where dread yet never so impressed" $(13,17,21,25)$. Nevertheless, there is still a nagging caveat that this is a blason, and blasons are erotic by nature. In this case, sex appears to be encroaching upon Death's territory, just as it did in Romeo's visit to Juliet's grave.

John Donne's “The Relic” provides another interesting departure from both the Amorous Mortality and Corpse Bride tropes already described. His speaker presents a future, in which the speaker's grave is broken up for the purpose of accommodating a second corpse. The speaker begs that if anyone should notice a bracelet of hair amongst his remains, they will leave it undisturbed. However, if his instructions go unheeded, it is likely that his remains, as well as the bracelet of his beloved's hair, will be treated as relics of holy lovers. In this poem, the grave is a surrogate bed, as indicated in the lines that read "For graves have learned that woman-head, / To be to more than one a bed" (34). Not only does "bed" have the sexual connotations described previously, but it is also linked with "woman-head," a reference to the term "maidenhead," which had been a term for female virginity since the fourteenth century ("Maidenhead, n.1"). The $O E D$ also lists several contexts in which the word "woman" has carried the connotation of a state of sexual maturity ("Woman, n. 6"). 
The speaker indicates that the bracelet of hair is a "device" that "might be some way / To make their souls at the last busy day / Meet at their grave, and make a little stay" (9-11). These lines present the reader with the image of the Last Judgment. Early Modern writers were extremely, sometimes bizarrely, preoccupied with the bodily resurrection promised by the Bible. Some theologians disagreed on the minutiae of this event, wondering if each body would contain exactly the same particles as in life or if every particle of the body was necessary to achieve this miracle (Bynum 594). Targoff seeks to discover what the bodily resurrection meant for Donne. She writes:

The idea that the kingdom of heaven will be filled with glorified human bodies was not, in itself, controversial... What was controversial, and what Donne struggles to prove repeatedly in his writings, is that the glorified bodies in heaven are essentially identical to the bodies we possess on earth. (18)

In fact, in this particular instance, it appears that Donne (or his speaker, at any rate), assumes that the heavenly bodies of the two lovers are not just identical in the sense that they are exactly alike, but they are identical in the sense that they are exactly the same. Thus, if the speaker wears a bracelet of his beloved's hair, they must meet on that "last busy day" because his body has a portion of hers, and she must gather up all the pieces before meeting her maker. In a somewhat macabre twist, the two lovers will "make a little stay," which could indicate some sort of sexual dalliance (9-11). In this instance, the living is not filled with lust for the dead, and the dead is not filled with lust for the living. Rather, "The Relic" seems to unite these two tropes. The Amorous Mortality-like speaker will unite with his Corpse Bride, making his grave the last earthly place of physical, possibly sexual, union for the two lovers. They will, theoretically, pass into eternity together, not apart. 
It is possible to read a certain legal ownership into the speaker's possession of part of his lover's corpse. By keeping part of her with him, he has the power to command her to come to his side at the Last Judgment. He is able to exercise a claim on her in both this world and the next. A similar concept can be found in "The Finger" by Howard Schwartz, a retelling of a sixteenth century Jewish folktale. The plot revolves around a young man named Reuven who is to marry his betrothed. The night before the wedding, Reuven and his two friends go out for a walk. They decide to go through the forest, and, as they go along, one of them "noticed something strange nearby. It was an object the size of a finger that stuck out of the earth" (227). The young men are amused to find this improperly buried corpse, and Reuven decides to put the wedding band intended for his bride on the finger and pronounce his wedding vows "three times, as the law requires" (227). As it turns out, the finger belongs to a dead woman who, in life "had never married and had thus been denied her hour of joy. And she was determined to receive after death what she had been denied in life" (229). The Corpse Bride claims Reuven as her husband, and, during Reuven's wedding to his living bride, the Corpse Bride appears, wearing the wedding band Reuven had placed on her finger in order to affirm her claim publicly. Reuven admits what he has done to the rabbi, who decrees that the rabbinic court must convene to determine the legality of the Corpse Bride's claim.

Reuven, his two friends, Reuven's parents, the living bride's parents, and the Corpse Bride are all called upon to give testimony regarding the situation. Reuven did, indeed, say his vows three times, and he did so in the presence of two witnesses, which would ordinarily make his marriage to the Corpse Bride valid. However, the rabbinic court eventually judges that Reuven's new vows to the Corpse Bride do not override the 
older vow to his living bride. They also claim that, since Reuven did not intentionally marry the Corpse Bride, he cannot be held accountable for them. "Finally," the rabbi points out, "there is no precedent for a claim on the living by the dead," and the "marriage is thus declared null and void" (229). The Corpse Bride "collapsed upon the ground and became again as one of the dead," and Reuven is allowed to married his living bride.

The Jewish legal system features heavily in this story, which emphasizes the importance of interpretation. The simplest interpretation of the law would have required Reuven to accept that he had married a corpse and consummate his marriage with her in keeping with the fact that a wedding vow is far more serious than a betrothal. However, the rabbinical court is able to take advantage of the lack of precedence by declaring that the earlier betrothal means that Reuven was not free to marry anyone but his betrothed, that intention matters, and that this sort of union has never been validated before, and it cannot be validated now. Just as Jove was able to find a flexible solution to Proserpine's problem, the rabbinical court finds a flexible solution that saves Reuven from a future of necrophilia.

In this case, Mortality, in the figure of the Corpse Bride, is not allowed to take possession of the living. However, this was a real threat that had to be dealt with. While this story does not affirm Mortality's hold over the living, it does affirm the interconnectedness between the ideas of mortality, sexuality and legality that is present in many other instances throughout the Early Modern Period. One wonders how this would have played out had it been a Corpse Groom, with all the authority of masculinity on his 
side, and a living bride, with few legal rights of her own, but it is possible that the motif of Amorous Death has already answered that for us.

The Corpse Bride trope does not conflate sex and death like the Amorous Mortality trope. Rather, it makes corpses, particularly female corpses, into erotic objects. In Juliet's case, her beauty is the ultimate source of her erotic potential, but that beauty becomes all the more marvelous because Romeo believes that she remains beautiful even in death. Her limit-experience with the finitude of death gives her beauty a new cachet. For Romeo, her living beauty had been noteworthy, but her dead beauty is miraculous.

Ophelia is also desirable as a corpse, but not because of her beauty. Rather, she is desirable as an object of mourning. Hamlet's feelings for her are ambivalent at best throughout the first four acts. However, after her death, he ready to give his life to be buried beside her, but only if her brother is making the same display. He is not ready to commit to her in any meaningful way unless he can express his anguish and anxiety at the finitude of death by one-upping her grieving brother. It is only as a corpse that Ophelia can be an object of desire for Hamlet, who is incurably fixated on the grave. Similarly, Surrey's blason about the corpse of Wyatt is only possible in Wyatt's death. The blason, besides being an erotic genre, is also a violent one. The body of the beloved is usually objectified and picked apart so that the speaker of the poem may look at each body part in turn. There is a fetishizing quality to this action. While it is normal for a male writer to complete this sort of project with regards to a living female, given their generally aggressive feelings towards their beloveds, this sort of aggression is unusual in the sort of homosocial relationship Surrey and Wyatt shared. However, Wyatt's limit-experience with the finitude of death creates an opportunity for Surrey to think of him not merely as 
a friend, but as an image of finitude deserving of contemplation. For the speaker of "The Relic," the focus is entirely on finitude, on the earthly side of the boundary of death. He and his beloved may look towards the infinitude of Heaven, the speaker truly anticipates the "little stay," the possible sexual encounter he and his beloved may have at the grave. Finally, "The Finger" could possibly be placed in Chapter I: Amorous Mortality, given the active part the Corpse Bride plays in the narrative. However, her ineffectiveness places her with the passive Corpse Brides. In any case, as with "The Relic," the narrative is primarily concerned with the erotic possibilities on the living side of the boundary of death. The Corpse Bride of "The Finger" does not seek to take her new husband back the land of the dead, as Dis had. Rather, she wishes to stay in the world of the living with him so that they may consummate their marriage. She crosses the boundary in reverse. 


\section{CHAPTER III}

\section{DEADLY PROPOSALS}

Juliet's false death has already been mentioned, but what of her true death? Mere minutes after Romeo breathes his last, Juliet awakens in her tomb. Friar Laurence attempts to convince her to join a convent, but she insists that she will stay with Romeo. She thinks to poison herself, but he has "drunk all, and left no friendly drop / To help" her (5.3.163-4). In an echo of the kisses Romeo bestowed just before his death, Juliet kisses his corpse, hoping that "some poison yet doth hang on them" (5.3.165). Her hopes are dashed, but she finds Romeo's dagger. She says, "O happy dagger, / This is thy sheath! There rust, and let me die" (5.3.168-9). With Romeo's death, their marriage is dissolved. Juliet's final act is to make the match that so many characters - her father, her mother, Paris, Romeo, even herself - have been predicting for her throughout the course of the play. However, rather than simply succumbing to Mortality, Juliet chooses it freely. She consummates her relationship with Mortality through the aid of a phallic weapon, the dagger that used to belong to her husband and hung near his literal phallus. This dagger now belongs to his corpse, which is both a figure of Mortality and Mortality's possession. This is also the moment where a dutiful editor usually notes that the word "die" was often used in the Renaissance as a euphemism for orgasm with no further explanation. This footnote is absent from my copy of the text, but the meaning is there, nonetheless. The beautiful young maiden invites Mortality's penetration and the 
subsequent pleasure this sexual union will bring. Juliet's death is filled with despair, but it is also filled with the ecstasy of choice. So much of her previous experience depends on others. Her parents attempt to choose her husband for her, she accepts the desperate advice of Friar Laurence, and her happiness is destroyed by a series of events that are not under her control - the deaths of Mercutio and Tybalt, the plague on the way to Mantua, etc. However, this young woman who was once considered the victim of Amorous Mortality's attentions turns this assumption on its head. Juliet chooses her own death, eagerly embracing it.

This may be similar to Ophelia's probable suicide. Having suffered disappointment in her love for Hamlet, as well as the shock of her father's death at Hamlet's hands, Ophelia experiences a period of madness ending with her death in a nearby brook. This occurs off-stage, but it is reported to Laertes, and the audience, by Queen Gertrude:

Therewith fantastic garlands did she make Of crowflowers, nettles, daisies, and long purples, That liberal shepherds give a grosser name, But our cold maids do dead men's fingers call them... When down her weedy trophies and herself Fell in the weeping brook. Her clothes spread wide, And mermaid-like awhile they bore her up... Till that her garments, heavy with their drink, Pulled the poor wretch...to muddy death. (4.7.167-82).

Gertrude describes this death as an accident, but it is clear that others have their doubts. The Gravedigger questions her Christian burial, since she "willfully seeks her own salvation" (5.1.2). As the funeral procession comes into view, Hamlet notes that, judging from the "maimed rites," the "corpse they do follow did with desp'rate hand / Fordo its own life" (5.1.197-9). Finally, when Laertes asks what other ceremonies can be 
performed for Ophelia, the Doctor of Divinity answers that these "obsequies" already performed "have been as far enlarged / As we have warranty. Her death was doubtful" (5.1.204-5). Clearly, the verdict everyone else has chosen is suicide.

Ophelia's impulse to deck herself in flowers falls in line with a few other details already mentioned, such as Proserpine's flower-picking, the flowers strewn on Juliet's grave, and the flowers that Gertrude will employ at Ophelia's funeral. As previously mentioned, flowers are symbols of fertility. It sounds as if Gertrude is describing some sort of pagan bride or a maenad caught up in Dionysian revelry, not a demure Elizabethan noblewoman. The image of her clothes creating a mermaid tale would prove erotic for Victorian sensibilities, and they may have seemed erotic to Shakespeare's original audience. Nineteenth-century artists, such as Sir John Everett Millais and Alexandre



Figure 2 Ophelia by Sir John Everett Millais, 1852. Tate Britain, London
Cabanel, would go on to paint Ophelia in the brook, wearing wedding white, floating suggestively on her back and decked in flowers (Fig. 8 and 9). It would appear that Ophelia, much like Juliet, considered her grave to be her bridal-bed and Death her chosen husband.

Figure 9 Ophelia by Alexandre Cabanel, 1883. Private Collection.

Shakespeare has one other heroine who dies an erotic death, but this is not a death of her choosing. In Desdemona's case, her

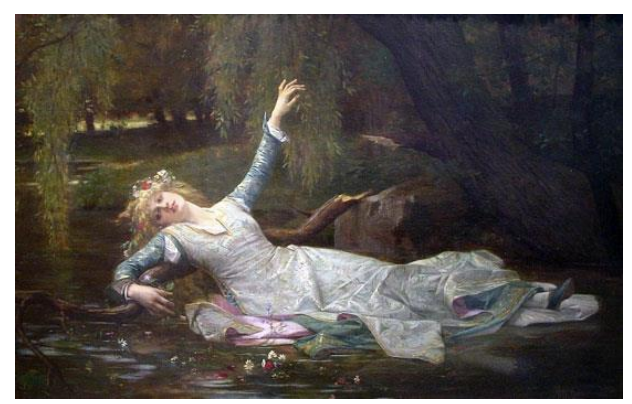


husband, Othello, has chosen to give her to Amorous Mortality, as Capulet had intended to give Juliet to Paris. Othello is rife with both sexual repression and sexual obsession. As soon as Othello and Desdemona are married, they are whisked away in separate ships to Cyprus, leaving no time for a honeymoon. Once there, the happy newlyweds never seem to have any time alone. They are constantly surrounded by other people, and the demands made on Othello's attention are high. One wonders if they managed to find time to consummate their marriage at all. Perhaps they have not; this would explain a few puzzling details. Why would such a newly married man fear for his wife's fidelity? Surely, they have been married too short a time for her to have grown bored with him unless she has not had a chance to enjoy him at all. Desdemona would only be able to carry on an affair with Cassio if she spent little time with Othello, which certainly appears to be the case. Also, why the fascination with the handkerchief? Besides the associations with Othello's mother, and his insistence that it magically "subdues" men to their wives, what else could it mean to Othello (3.4.56-61)?

Hodgson identifies the handkerchief with Desdemona's sexual reputation. One could argue that the handkerchief is the physical symbol of Desdemona and Othello's love, and Othello is upset because Desdemona seems to have given her love away to another man. Hodgson disagrees. He views the handkerchief as the tangible emblem of Desdemona's intangible reputation. According to Hodgson, the strawberry pattern is aligned with the bloody sheets involved in two different events: the loss of Desdemona's virginity and Desdemona's death. He argues that, in Othello's mind, the red strawberries resemble the blood that would ordinarily accompany a broken hymen on the night of a virgin's wedding (Hodgson 319). To Othello, giving this spotted love token to Cassio is 
a symbol for the virginity he believes she has sacrificed, as well. This might explain Desdemona's insistence that Emilia put her wedding sheets on the bed before Othello comes (4.2.108). Desdemona's "remember" may be directed both at Emilia, who needs to remember to do this for her, and at Othello, who should remember that they have not consummated their marriage yet, which is why the wedding sheets are clean (Hodgson 319). The other event, Desdemona's death, is the event that actually occurs. Just before he leaves the stage on his way to Desdemona's bed, Othello vows that "Thy bed, luststained, shall with lust's blood be spotted," (5.1.36). However, Othello does not follow through with this threat. Rather, when the time comes, he decides to smother her, saying, "I'll not shed her blood, / Nor scar that whiter skin of hers than snow" (5.2.3-4). The deciding factor is her beauty. Othello may wish to rob her of her life, but he does not wish to spoil her as an aesthetic object, another echo of Romeo's admiration for the sleeping Juliet. Hodgson says, "Appropriately, emblematically, Desdemona dies on spotless wedding sheets," the symbol of her chastity (Hodgson 319-20).

Is her death really as pure as the picture Hodgson paints? Remembering that she is smothered in her bed, we must imagine the scene playing out as it would on stage, as Shakespeare intended. Imagine Desdemona asleep in bed when Othello arrives. She is, naturally, in her nightgown, a garment that was, at the very least, understood as an erotic object. Othello kisses her twice, like Romeo, and she awakens. He accuses; she denies. In his fury, he throws her on the bed, straddling her as she resists. Their bodies move much as they would were they in the throes of passion. However, when they finally grow still it is not because they are satisfied, but because Desdemona has given out. She is not dead - her actual death will not occur until after she has declared herself "falsely, falsely 
murdered" and "guiltless," but all of her energy has been drained out of her (5.2.126, 5.2.132). As it turns out, Othello suffers the bloody death he had originally designed for Desdemona. After all is revealed, Othello somehow seizes a weapon and stabs himself. As Hodgson notes that "Othello, falling mortally self-wounded beside [Desdemona] on the bed, stains [the sheets] with his own blood" (Hodgson 320). Othello may have left Desdemona with no choice, but he does choose Death for himself.

This paper treats these erotic deaths as an extension of the tropes already mentioned, but they might be better described as the culminations of the Amorous Mortality and Corpse Bride tropes. These deaths are the most explicit depictions of the Early Modern impulse to conflate the limit-experiences of sex and death. Juliet takes Mortality as her lover in an extremely carnal fashion, while Ophelia dresses herself for a pagan celebration before transforming herself into an erotic mermaid. She allows the water to drag her down while covered in flowers, just as Proserpine was dragged to the Underworld. Finally, Desdemona dies in a death scene that looks more like a rape and is soon followed by her husband. The suicides of Juliet, Ophelia and Othello are noble because they seek the limit-experience of death and finitude willingly. Desdemona's death stirs pity because she is forced into, just as Juliet's family tried to frame her as Mortality's victim. 


\section{CHAPTER IV}

\section{THE AMOROUS DIVINE}

The Early Modern Period inherited more myths of amorous divinities than that of Dis and Proserpine. A common trope was the love of an immortal for a mortal. Jupiter, or Jove, featured in many of these tales, usually appearing to a mortal woman in a different form and impregnating her, much to his wife Juno's displeasure. Ovid, for instance, includes such myths as the story of Io, in which Jove appears to the maiden Io in a "foggie mist" that allows him to use "her as he list[s];" the story of Europa, in which Jove abducts Europa in the form of a bull "as white as any winters snow;" the story of Semele, the mother of Dionysus; the story of Danaë, in which Jove impregnates Danaë in a "golden shower" with the hero Perseus; and the story of the hero Hercules, who was the son of Jove and the mortal Alcmene (1.743-4, 2.1065, 3.316, 4.751, 9.340-6).

Each of these stories depicts the powerful, supreme deity in a sexual union with a mortal. Jove's unusual sexual tastes have been a source of fascination for millennia, but perhaps a more important tale of divine love is that of Cupid and Psyche, which links the trope of Amorous Mortality with the trope of the Amorous Divine. The most detailed account of this story is found in Apuleius' The Golden Ass. In this story, a beautiful princess named Psyche is worshipped at the expense of the goddess Venus, and, in retaliation, Venus persuades her son, Cupid, to make Psyche fall in love with "some perfect outcast of a man-someone who has lost rank, fortune, everything" (98). 
However, Cupid falls in love with Psyche and spares her from the fate assigned to her by his mother. The Oracle of Apollo informs Psyche's parents that she will become the bride of a "dire mischief" of a husband, "a winged pest" who is even feared by Jupiter, the king of the gods (100). They interpret this to mean that Psyche will be taken by a monster, but the "winged pest" is, of course, the winged Cupid, whom the narrator of the tale describes as "a wicked boy, with neither manners nor respect for decencies" and has the power of love over everyone and everything, even Jupiter himself, whom Cupid is "always shooting" with his "arrows...defil[ing him] with mortal love affairs" $(98,141)$. For this reason, Psyche is led to a mountain in a macabre wedding processional to await her monstrous husband. She is carried by the West Wind to Cupid's palace where she is waited on by invisible servants. Psyche's husband visits her at night and leaves before daybreak. She is never allowed to see him, or know his true identity, but she falls in love with him. However, the threat that she has married a monster becomes too great, and one night she lights a lamp, revealing that her husband is Cupid, the god of love. She accidentally burns him, he awakens, and he abandons her for her disobedience. After Psyche performs a number of dangerous tasks for the angry Venus, including a trip to the Underworld and back, Cupid forgives her and arranges for Jupiter to persuade Venus to put aside her anger and recognize Cupid and Psyche's marriage, and make her immortal.

This myth serves as an interesting bridge between the Amorous Mortality and Amorous Divine tropes because death is a reoccurring image within the tale. Psyche's "dreadful wedding" features torches "that burned low with sooty, spluttering flame;" "a querulous Lydian lament," instead of a "happy wedding march;" and "funereal howls" (100). In the ancient world, torches were carried in both wedding and funeral 
processions. The sooty nature of the torches elides these traditions, allowing the wedding and the funeral to share this ceremonial space. Rather than a day of celebration, Psyche's wedding day becomes "a day of public mourning" for the "calamity that had overtaken the royal house" (100). Just as Juliet pondered a union with Mortality, Psyche leads the procession, not as a joyful bride, but "with the air of a woman going to her grave, not her bridal bed" (101).

Neumann reads this wedding procession as a characteristic of the matriarchal cults associated with ancient goddesses, particularly the Eleusinian Mysteries, which were devoted to Demeter and Kore-Persephone, the Greek equivalents of Ceres and Proserpine. Neumann puts it thus:

Seen from the standpoint of the matriarchal world, every marriage is a rape of Kore, the virginal bloom, by Hades, the ravishing earthly aspect of the hostile male. From this point of view every marriage is an exposure on the mountain's summit in mortal loneliness, and a waiting for the male monster, to whom the bride is surrendered. The veiling of the bride is always the veiling of the mystery, and marriage as the marriage of death is a central archetype of the feminine mysteries...marriage, as the matriarchate recognized, is primarily an abduction, an acquisition-a rape. (62-3)

The sexual relationship of marriage becomes a site for transition. Transitioning from virgin (or, at least, unmarried) to fertile sexual being is fraught with anxiety, and, in the minds of members of the matriarchate, it is similar to death, the ultimate site of transition from the mortal world to the Underworld. Thus, marriage represents the death of the virgin and the birth of the future mother through a violent, deadly sexuality. More than that, as Dowden notes, "kore," usually translated as "girl," is not quite synonymous with "parthenos," or "virgin" (2). To be a "kore" is to be someone's daughter, just as to be a "gyne," is to be someone's wife (Dowden, 2). Both terms imply a relationship that carries the connotation of belonging to the other individual. A "kore" is the possession of 
her father, and a "gyne" is, as Neumann phrases it, the "acquisition" of her husband (63). However, Psyche's case is special, for her husband is not a mortal man, but a god. He is not simply a lover; he is also one of the most powerful beings in the universe. Likewise, her marriage is not merely the death of one identity and the birth of another, the transition from one household to another. Her marriage is a deification, a transition from one plane to another.

As Huskinson notes, the myth of Cupid and Psyche "provides a model for the testing of love through suffering, for subsequent reunion with the beloved... and a 'happy ending'...But since Psyche also stands for the soul...this theme of union reached through trial has a spiritual as well as physical value" (102). Thus, this myth became a common feature of both adult and child Roman funerary art in the second and third centuries. Furthermore, Cupid and Psyche were often juxtaposed with scenes of Dionysian revelry, which "hint at religious initiation as the route to this union" (Huskinson 42-43, 102).

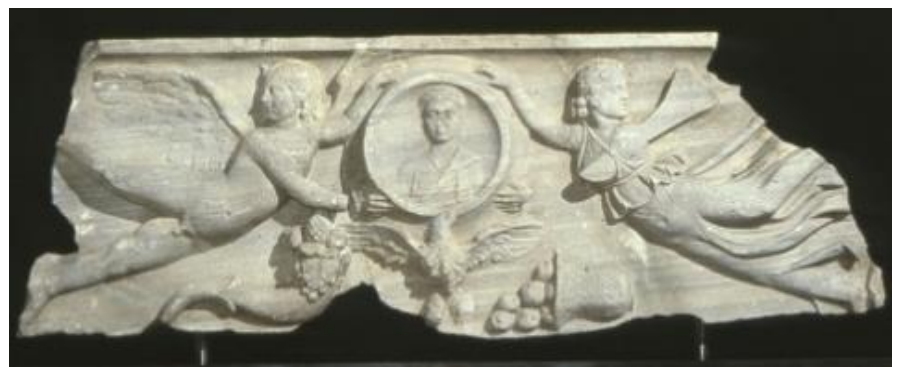

Figure 10 An early 4th century A.D. Roman sarcophagus panel featuring Cupid and Psyche holding up the portrait of the owner of the sarcophagus. Notice that Cupid (on the left) has bird wings, and Psyche (on the right) has butterfly wings. Indianapolis Museum of Art, Indianapolis.

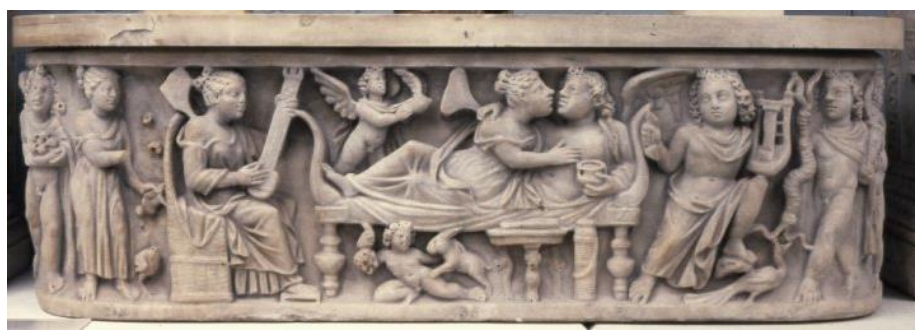

Figure 11 A 3rd century Roman sarcophagus depicting the wedding feast of Cupid and Psyche, who are reclining on the couch. Sarcophagus, 3rd century. The British Museum, London. 
According to Huskinson, Christian funerary art "drew heavily on earlier imagery," but it is "essentially prospective, looking towards the afterlife...[W]orldly experience as a means of self-validation loses much of its old force" $(68,119)$. Meanwhile, "Cupids seem to be obvious subjects for child sarcophagi because they are 'eternal children'...Cupid imagery also offers opportunities to display the prettiness and sentimentality which adults often like to associate with children" (Huskinson 105). While pagan sarcophagi often feature Cupid(s) without Psyche in various activities and poses, such as facilitating romantic encounters, athletics, carrying arms or armor, playing games, hunting, racing chariots, etc., Cupid(s) rarely figure in early Christian sarcophagi without Psyche (Huskinson 41-7, 68). It is possible that Psyche's association with the soul (her butterfly wings symbolize the soul, her name means "soul") made this pagan myth of divine love attractive for early Christians, which allowed the myth of Cupid and Psyche to continue while Cupid(s) alone fell to the wayside. In fact, the figures of Cupid and Psyche are often juxtaposed with figures of the Good Shepherd, an image of Jesus Christ derived from such biblical verses as John 10:11, in which Jesus says, "I am the good shepherd: the good shepherd giveth his life for his sheep" and John 10:14, in which Jesus says, "I am the good shepherd, and know my sheep, and am known of mine" (Huskinson 68, King James Bible).

Huskinson doubts that this was an effort on the part of early Christians to "Christianize" this myth, but the tale may have resonated with early Christians, particularly those with Gentile heritages, attempting to express their relatively new theology through pre-existing imagery. Psyche's allegorical identification with the soul, her inability to see her divine husband, her transgression, her worldly sufferings, and her 
eventual union with her divine lover among the gods could have translated easily into Christian theology, which was concerned with the prioritization of spirit over flesh, a relationship with an invisible deity who encourages his followers to "walk by faith, not by sight," sin, earthly trials followed by heavenly rewards, and union with the divine in Heaven (2 Cor. 5:7). It is also certain that Fulgentius, a fifth century Christian writer attempted to read the myth of Cupid and Psyche in a Christian allegorical context, though he had very different conclusions. He identifies Psyche with the spirit and Cupid with "greed," which is "taken with the spirit and links itself to her," persuading her not to look upon itself, lest she "learn the pleasures of greed" (Fulgentius 89). Far from allowing Cupid to stand in for God metaphorically, this reading equates Cupid/Love with Greed, which is a sin, but it does indicate that Christians were not ready to discount the allegorical value of pagan myths, particularly myths with such fertile interpretive possibilities.

This suggestion of sexual or marital union with the divine becomes even more interesting when one considers a few select passages from the Gospels. The Christian relationship to Christ is compared to a marital relationship with Christ as the Bridegroom and the Church as the Bride. For instance, in the Parable of the Ten Virgins who are awaiting their bridegroom, the five wise virgins who brought enough oil for their lamps, and did not have to leave to buy more, are able to go into the wedding with the bridegroom, but the five foolish virgins who had to buy oil for their lamps are left behind. The five wise virgins are identified as followers of Christ who are prepared for his coming, but the five foolish virgins are unable to enter the kingdom of Heaven because they are unprepared (Mt. 25.1-13). Meanwhile, John the Baptist says something similar 
when he denies that he is the long-awaited Messiah and identifies himself as the Messiah's herald. John says:

Ye yourselves bear me witness, that I said, I am not the Christ, but that I am, sent before him.

He that hath the bride is the bridegroom; but the friend of the bridegroom, which standeth and heareth him, rejoiceth greatly because of the bridegroom's voice: this my joy therefore is fulfilled. (Jn. 3.28-29)

This idea of fulfillment is carried through in other pieces. Death was, as Hamlet says, "a consummation / Devoutly to be wished" (Hamlet 3.1.64-5). The oldest use of the word consummation recorded in the $O E D$ dates to ca. 1398 and carries the connotation of "perfecting" an action, which the $O E D$ identifies as no longer part of common parlance, but could be viewed as influential in Shakespeare's understanding ("Consummation, n"). The second definition, the completion of an act, seems closer to Hamlet's meaning. The $O E D$ cites these exact lines as the origin of the definition of a "fitting, crowning, or inevitable outcome" ("Consummation, n."). Among other things, consummation is listed as death itself, or as the Day of Judgment, but another usage, that of binding a marital or otherwise sexual relationship through sexual intercourse, is an interesting option. The $O E D$ records this usage as early as 1530 , and it was a highly charged term during the time of the King's Great Matter, Henry VIII's much-contested divorce from Catherine of Aragon. Catherine's claim that she did not consummate her marriage with Henry VIII's older brother, Prince Arthur, was the basis for her claim to be Henry's wife. However, Henry's claim that Catherine did, in fact, consummate her marriage with Arthur was the basis for Henry's argument that his marriage to Catherine was incestuous and, therefore, invalid. This argument and Henry's subsequent divorce made way for his next queen, Anne Boleyn, the mother of Elizabeth I, who was queen 
regnant for much of Shakespeare's early life and career. In the Renaissance mind, all of these meanings are possible, and probable, in this instance. Bynum writes this about Early Modern thought:

The moment of dying became more and more highly charged; it became the moment at which not only one's fate but also one's significance was judged...Dying became an intense physical and emotional experience, associated with suffering, affective response, and self-understanding. Death was the moment of self-knowledge in which one moved from one's own misery...to union with the glorious suffering of the dying Christ. (592)

The intense physicality of Death, combined with the intense spirituality of this union with Christ, produced an understanding of Death that was both agonized and ecstatic.

Bynum describes the experience of Julian of Norwich, a fourteenth-century mystic, as "both ecstasy and excruciating pain" (Bynum 593). According to Julian’s book, at the age of "thirty year old and a half," she suffered from a "bodily sickness" that made her feel as if her body was "dead from the middes downward" (414). As her "sight began to fail," Julian claimed that everything "waxed dark about me in the chamber as if it had been night, save in the image of the cross, wherein held a common light" (414). Suddenly, all of her pain was gone, and she wished to take on the stigmata, the wounds of Christ, "for I would that his pains were my pains, with his passion and afterward longing to God" (415). Julian wishes to experience a sort of carnal knowledge of Christ by experiencing the wounds inflicted upon Him during the crucifixion. Her wish that "his pains were my pains" also carries some of the weight of the wedding vows, "for better or for worse, for richer or poorer, in sickness and in health," which, as we shall see, were almost certainly a standard part of the English wedding ceremony in the Medieval Period.

One of Julian's contemporaries and fellow mystics, Margery Kempe, describes a more traditionally carnal relationship with Christ than Julian's. Kempe claims that God 
the Father came to her in a vision and said, "Daughter, I will have you wedded to my Godhead, for I shall show you my secrets and counsels, for you shall dwell with me without end" (431). When Kempe does not answer, "Christ Jesus, whose manhood she loved so much," asks if this will please her (431, emphasis mine). Again, she does not answer, but "wept wonder sore, desiring to have still himself and in no way to be parted from him" (431, emphasis mine). Eventually, Kempe is married to God Himself, who makes the traditional vows that she will be his "wedded wife, for fairer, for fouler, for richer, for poorer, as long as you be buxom and obedient to do what I bid you do" (431). Kempe also claims that God gave her a "flame of fire wonderfully hot and delectable and right comfortable" to burn in her breast (432). This is the "fire of love" that will always remind her that "the Holy Ghost is in" her, and that she and God are "joined together without end" (432). Kempe tells us that her marriage with God is not a marriage in name only, but a fully consummated marriage. God the Father says to her:

For it is suitable for the wife to be homely with her husband. Be he never so great a lord and she so poor a woman when he wedded her, yet they must lie together and rest together in joy and peace. Right so must it be between you and me...Therefore must I needs be homely with you and lie in your bed with you... and you may boldly, when you are in your bed, take me to you as your wedded husband...And therefore you may boldly take me in the arms of your soul and kiss my mouth, my head, and my feet as sweetly as you will. (433, emphasis mine)

Julian of Norwich and Margery Kempe's visions may be spiritually connected to the visions described by Saint Teresa of Ávila (1515-1582) in her autobiography. Saint Teresa says:

Beside me, on the left hand, appeared an angel...In his hands I saw a great golden spear, and at the iron tip there appeared to be a point of fire. This he plunged into my heart several times so that it penetrated to my entrails. When he pulled it out, I felt that he took them with it, and left me utterly consumed by the great love of God. The pain was so severe that it made me utter several moans. The sweetness 
caused by this intense pain is so extreme that one cannot possibly wish it to cease... (Saint Teresa of Ávila 210, emphasis mine).

The erotic nature of this vision is obvious. The saint claims to be penetrated over and over again with a phallic spear that fills her with such orgasmic ecstasy that she moans with both pain and satisfaction, leaving her with nothing but desire - for God. The eroticism of this vision was not naively lost on Renaissance readers. They did not interpret this vision as a nun's chaste love for God, nor did they reject her visions as the fevered fantasies of a sexually repressed nun. Rather, Renaissance thinkers chose to celebrate her mystical union with the divine.

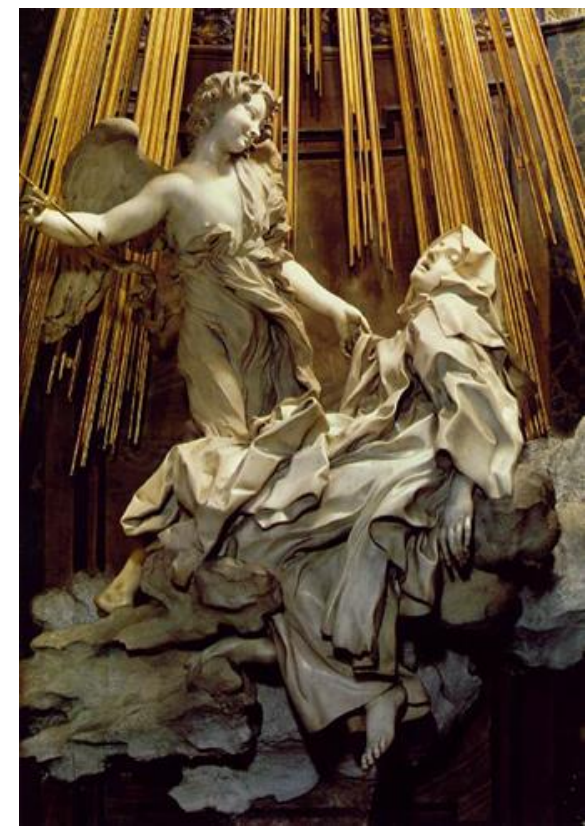

Figure 12 The Ecstasy of St. Teresa by Gian Lorenza Bernini, 16471652. Santa Maria della Vittoria, Rome.

Perhaps the most noteworthy artistic representation of this vision is Bernini's statue, The Ecstasy of St. Teresa (Fig. 12). Saint Teresa reclines suggestively in her flowing garments while the angel stands above her, holding the spear or arrow he has been using to stab her. A close-up of her face reveals her look of intense spiritual and physical passion (Fig. 13).

Figure 13 Details of the Ecstasy of St. Teresa by Gian Lorenzo Bernini, 1647-1652. Santa Maria della Vittoria, Rome.

This vision and its artistic representation is reminiscent of two other women already discussed, Psyche and Juliet Capulet. Just




as Psyche was visited in her bedchamber by a winged Cupid bearing arrows, so is St. Teresa visited by a winged angel bearing a spear. Furthermore, just as Juliet achieves an orgasmic end with a phallic dagger, St. Teresa achieves an orgasmic ecstasy with a phallic spear. While St. Teresa describes her divine lover as an angel, it is possible to think of this angel as God's proxy. In the Judeo-Christian tradition, angels are "the attendants and messengers of the Deity" (“Angel, n. 1.”). Angels act strictly under orders from God. Therefore, St. Teresa and her readers would not simply perceive the angel as a divine lover, but as acting as an extension of God Himself.

Achsah Guibbory notes that, "In the history of Western religion, women have had a far more ambiguous relationship to the sacred than men," which may explain this tendency of female mystics to explore their relationship to God in such carnal terms (“The Gospel” 191). These particular mystics - Julian of Norwich, Margery Kempe and St. Teresa of Ávila - were all Catholics. As such, they had access to the adoration of the Virgin Mary, who is also known as the Queen of Heaven, indicating a consort relationship with God the Father, the King of Heaven. Just as various mortal women fell prey to the attentions of Jove and bore his children, the Blessed Virgin is impregnated by God, though, unlike Jove's paramours, the Blessed Virgin is said to marry the human Joseph while remaining chaste until her death, allowing her to stay faithful to the divine father of her son. While the Gospels sanitize Christ's conception, the pagan myths of the Amorous Divine were still available to Early Modern thinkers. The Protestant Reformation may have "deepened the distance between women and the sacred" by removing the adoration of the Virgin, closing the doors to convents, and emphasizing the importance of marriage and family life, but one Renaissance woman in particular seems 
to have been determined to preserve the romantic/erotic relationship to God available under Catholicism - Aemilia Lanyer ("The Gospel” 192).

In her Salve Deus Rex Judaeorum and its dedicatory poems, Lanyer revives the trope of the Amorous Divine by encouraging women such as "the Ladie Susan, Countesse Dowager of Kent, and Daughter to the Duchesse of Suffolke," to "Take this faire Bridegroome in your soules pure bed" ("To the Ladie Susan" 42). The subject of Salve Deus Rex Judaeorum is, ostensibly, the Passion of Christ, but Lanyer dwells primarily on the untrustworthiness of the men surrounding Christ and the sympathy and faith of the female figures, including Eve, Pilate's Wife, the mourning women of Jerusalem, and the Virgin Mary, who weeps over the fate of "Her Sonne, her Husband, Father, Savior, King" (Salve 1023, emphasis mine). Her erotic relationship with God is emphasized again when the narrator calls Mary the "Servant, Wife, Mother, and Nurse / To Heavens bright King, that freed us from the curse" (Salve 1087-8, emphasis mine). This relationship is also contrasted with notable romantic relationships, such as that of Antony and Cleopatra, which "Can no way be compared unto" the relationship between Christ and the "vertuous Ladies" who marry the "Bridegroome" (Salve 1409-10, "Vertuous Ladies" 9). Antony and Cleopatra's relationship is found wanting because she deserted him in his need, and their relationship was founded on pride, unlike the love the Ladie Margaret Countesse Dowager of Cumberland bears for Christ, since her love is guided by humility and faithfulness (Salve 1409-1440). Rather than these earthly relationships, the Virgin Mary, again, becomes the model for Christian women.

Lanyer seems to have a very specific agenda in her attention to the Amorous Divine. Guibbory points out that "Lanyer praises those women whose devotion to Christ 
has taken the place of earthly, human marriages," ("The Gospel" 202). While the Protestant Reformation sought to eliminate celibacy (preferring to emphasize God's command to "Be fruitful, and multiply, and replenish the earth, and subdue it"), and encouraged the subjugation of women by their husbands, Lanyer "uses the language of love and marriage to reject marriage in favour of [the]... socially revolutionary stance of those women and men in the early centuries of Christianity who...chose virginity, repudiating the institution of marriage that was the foundation of their society," one that put women under the authority of men (Gen. 1:28, "The Gospel” 203-4). Rather, by taking Christ as their husband, women could be assured of a special place in the scheme of the sacred, as well as reject the power of earthly husbands.

While these erotic relationships with God are especially vivid for female mystics, this relationship with the Amorous Divine is not reserved solely for women. Donne's "Batter my heart, three-person'd God," is representative of this type of relationship, one that will take on the connotations of God as lover and speaker as the object of God's affection. At first, the deity is depicted as a gentle force in the speaker's life. Donne's speaker says to God, "you / As yet but knock, breathe, shine, and seek to mend" (1-2). Therefore, the speaker believes that God is participating in traditional actions based on scripture. For instance, when the speaker says that God "knock[s]," he is almost certainly referring to the Book of Revelation, in which Christ says, "Behold, I stand at the door, and knock: if any man hear my voice, and open the door, I will come in to him" (Rev. 3.20). When the speaker says that God "breathe[s]," he is likely referring to the Book of Genesis, in which God breathes the breath of life into Adam's nostrils (Gen. 2.7). Or, when the speaker says that God "shine[s]," he is likely referring to the Gospel of John, in 
which Christ says, "I am the light of the world: he that followeth me shall not walk in darkness, but shall have the light of life" (Jn. 8.12). Finally, when the speaker says that God "seeks to mend," it is a probably reference to stories about Christ's healing powers, such as the miracles of Jesus healing the ten lepers, the blind man of Bethsaida, and the deaf mute at Decapolis (Lu. 11-19, Mk. 8:22-26, Mk. 7:31-37). Donne's speaker lists positive images of a nurturing deity, relying heavily on an active, benevolent God and a passive speaker. However, they are simply not enough for the speaker, who wants God to "Batter [his] heart," "break, blow, burn, and make [him] new" (4). These requests are more intense and, in some cases, more violent versions of God's traditional actions. "Knock" becomes "break," "breathe" becomes "blow," "shine" becomes "burn," and the action of mending becomes the action of making new.

The speaker recognizes that God is already a participant in their relationship, but the speaker says, "I like an usurp'd town t'another due / Labor t'admit you, but oh, to no end" (5-6). The speaker has attempted to respond to God's gentle advances, but he has failed, saying, "dearly I love you, and would be loved fain / But am betroth'd unto your enemy" (9-10). This is the point at which the relationship between God and the speaker becomes an explicitly sexual one. The usurp'd town laboring to admit an outsider is a metaphor for the sexual act. Foucault explains that traditionally "in the practice of sexual pleasures two roles and two poles can be clearly distinguished...that of the agent and that of the 'patient' - as Aristotle says, 'the female, as female, is passive, and the male, as male, is active" (Use of Pleasure, 46). God takes on the active "masculine" role, and the town, the speaker, admitting this masculine outsider takes on a passive "feminine" role. Furthermore, the speaker claims to have been "usurp'd" by, and "betroth'd" to, God's 
"enemy," Satan or sin. The speaker asks God to "Divorce" him from his devilish fiancé, so that the speaker's being may be reserved entirely for God (11). Finally, in a somewhat disturbing turn of events, the speaker appears to ask God to enslave and rape him, saying, "I / Except you enthrall me, never shall be free, / Nor ever chaste except you ravish me" (13-4). These two lines refer to biblical metaphors, the slave of Christ and the Bride of Christ. The Epistle to the Romans says:

Know ye not, that to whom ye yield yourselves servants to obey, his servants ye are to whom ye obey; whether of sin unto death, or of obedience unto righteousness?

But God be thanked, that ye were the servants of sin, but ye have obeyed from the heart that form of doctrine which was delivered you.

Being then made free from sin, ye became the servants of righteousness. (Rom. 6.16-18)

This is a particularly interesting paradox because it claims that because of his relationship with God, a man may be both free, in the sense that he is freed from sin, and enslaved, in the sense that he is enslaved to God. This already problematic metaphor becomes a darker image in conjunction with the Bride of Christ metaphor. The Epistle of Paul the Apostle to the Ephesians says, "Wives, submit yourselves unto your own husbands, as unto the Lord. For the husband is the head of the wife, even as Christ is the head of the church: and he is the saviour of the body" (Eph. 5.22-3). Meanwhile, according to The First Epistle of Paul the Apostle to the Corinthians states that every individual member of the Church joins together to create "one body" (1 Cor. 12.12-4). As a member of the church, the speaker is, through synecdoche, the Bride of Christ because he is a part of the Church, and the speaker must "submit" to his heavenly husband. This section is specifically about the issue of obedience in the domestic sphere, but it is hardly a stretch to interpret this submission as sexual in nature, as well. As the Bride of Christ, the 
speaker may only be chaste if his intercourse is with God, the savior of his body, and with no one else, especially not the enemy. Furthermore, this metaphor is used again in the Book of Revelation, which says:

And there came unto me one of the seven angels which had the seven vials full of the seven last plagues, and talked with me, saying, Come hither, I will shew thee the bride, the Lamb's wife.

And he carried me away in the spirit to a great and high mountain, and shewed me that great city, the holy Jerusalem, descending out of heaven from God.

(Rev. 21.9-10)

The speaker reinforces his claim to being the true Bride of Christ by depicting himself as a "town," the city of Jerusalem, but the speaker does not believe he is capable of free participation, since he has been "usurp'd," enslaved by sin. Therefore, he requires the freedom of enslavement by God. However, the speaker believes that God must take all of the initiative, perhaps thinking of the Gospel of John, in which Christ says, "No man can come to me, except the Father which hath sent me [to] draw him" (Jn. 6.44). This is why the speaker believes that God must "ravish" him. As a human being, the speaker is incapable of reaching God on his own. Rather, God must enter the speaker, who can neither draw God in, nor hinder Him once He has reached His decision.

The situation in "Since she whom I loved hath paid her last debt" is another example of God as lover. The opening four lines explain that the speaker's mistress or wife has died, her "soul" having been "ravish'd" to "heaven," apparently claimed in a sexual fashion by an amorous deity, much as Ganymede is swept up to Mt. Olympus by the eagle of Jove in Book 10 of Ovid's Metamorphoses (3). As a result of this, the speaker's "mind is set" "Wholly in heavenly things," and the speaker's "mind" "seek[s]" "God" (4-6). God now "woos [the speaker's] soul," in repayment for the love the speaker lost when his mistress/wife became the object of God's affections and died (10). 
Yet, God has reason to fear that the speaker may give his "love to saints and angels, [which are] things divine" but ultimately inferior to God Himself (12). Worse yet, the speaker may turn to "the world, flesh" or even "the devil," as did the speaker of "Batter my heart, three-person'd God" (14). In this poem, God is a lover full of "tender jealousy," who suspects that the speaker will reject His advances in favor of His rivals. This is, no doubt, a reference to The Book of Exodus, which says:

Thou shalt not make unto thee any graven image, or any likeness of any thing that is in heaven above, or that is in the earth beneath, or that is in the water under the earth.

Thou shalt not bow down thyself to them, nor serve them: for I the Lord thy God am a jealous God, visiting the iniquity of the fathers upon the children unto the third and fourth generation of them that hate me. (Ex. 20.4-5)

The jealousy described in The Book of Exodus is that of a God forbidding His people from worshipping other deities. However, the jealousy of "Since she whom I loved hath paid her last debt" is that of a jealous husband or lover concerned that His beloved, the speaker, is giving access to his sexuality, which is the sole right of the husband/lover God, to others.

If the trope of the Deadly Proposals is the culmination of the other tropes, the Amorous Divine is in sharp conflict with them. The other three tropes all affirm Mortality's ultimate ownership over everything that lives. However, the Amorous Divine attempts to disprove such a cynical conclusion. The myth of Cupid and Psyche depicts Psyche, a mortal woman, crossing the boundaries from finitude to infinitude through the limit-experience of sexuality. By marrying the immortal Cupid, Psyche is transformed into an immortal herself. This was a powerful model for early Christians who were seeking to define their incomprehensible relationship with God. Following Cupid and Psyche's lead, early Christians considered Christ to be their Bridegroom. Their marriage 
with Him served much the same function as Cupid and Psyche's, defeating the finitude of mortality by leading Christians into the infinitude of immortality as the eternal Brides of Christ. This was taken quite literally by mystics such as Margery Kempe, who claimed to have married God in a binding ceremony and to have consummated their marriage in a carnal limit-experience. Margery Kempe was, possibly, an influence on Aemilia Lanyer, a female poet who sought to find the place of women in the new scheme of the androcentric Post-Reformation Protestant Christianity by encouraging women to define their spiritual limit-experiences in erotic terms. However, Christ was not only considered the Bridegroom of women; men could enter into a romantic relationship with God, as well, like the speaker of John Donne's "Batter my heart, three-person'd God," who begs God to make his limit-experience as intense and physical as possible, even to the point of rape. While the use of such erotic imagery in the context of religion may seem questionable to a twenty-first century audience, the intensity of erotic desire made it the most appropriate imagery available to describe the Christian relationship with God. 


\section{CONCLUSIONS}

The question that has driven this investigation is, "Why are sex and death so thoroughly intertwined throughout the periods discussed, and how is this further complicated by the eroticism of spirituality?" Perhaps the answer lies in the recurring theme of control. Mortality is consistently granted ownership. Death marries Life; all things go to Death. From the Ancient world through the Renaissance and beyond, sex has had legal implications. The father had the right to marry his daughter to whichever suitor he chose, and inheritance was tied up in the legality of marriage and the legitimacy of offspring. Sex was a form of control, primarily of individual legal rights. Death, however, is uncontrollable and unknowable. It is also inevitable and irresistible. It is an image of the finitude of humanity, but what lies beyond its limits transforms this finitude into infinitude. Religion states that death has the possibility to mean the transition from the mundane to the glorious, which is why Death is a "consummation / Devoutly to wished" (Hamlet 3.1.64-5). However, the fact that the limit of death is forced upon the living has always frustrated mankind. Mortality appears to have complete control, and this anxiety is often expressed, particularly in the periods discussed, through the lens of sex, another finite limit-experience. In many cases, Death is the sexually dominant partner, a metaphor that expresses mankind's anxieties concerning Mortality's dominance over life. This is why Romeo and Capulet mourn Juliet's passing, or the speaker of "The 
Apparition" imagines avenging himself on his mistress by haunting her into an early grave.

In other cases, the living are enamored of Mortality and admiring of those who have crossed over to know the unknowable, who have achieved infinitude by breaking through the barrier of finitude. This is why Romeo cannot take his eyes off his (supposedly) dead wife, or Surrey ponders the transfigured body of his friend, Wyatt. Finally, in some cases, the living choose to run to Death's arms on their own terms, seeking the limit-experience that will allow them to cross over from the finite to the infinite, rather than waiting to undergo that transformation passively. Aristotle claimed that tragedy is responsible for the arousal of "pity and fear," as well as "the catharsis of such emotions" (Aristotle 47-9). While the true meaning of "catharsis" is unclear, one of the interpretations that has stood the test of time dictates that the audience identifies with the tragic hero, witnesses his/her downfall, and experiences the purgation of their own pity and fear by seeing the tragic hero die with courage and grace. Juliet, constantly dominated by men, is a heroine because she takes control and chooses her own death. Ophelia, similarly dominated and driven to madness, is a heroine for the same reason. This tension comes to a head in Othello, where Desdemona is forced into Death's arms by a man who soon chooses to take his own life. By seeing these heroes and heroines actively take control by choosing their own deaths, often in erotic ways, the audience is purged of the pity for mankind's thralldom, as well as the fear of Death. Through this symbolic carnal knowledge, death becomes knowable, and the audience can admire this journey to infinitude vicariously. 
However, for Christians in the Early Modern Period, death is never the end of the story. According to John 3:16, one of the most quoted Bible verses, "For God so loved the world, that he gave his only begotten Son, that whosoever believeth in him should not perish, but have everlasting life." St. Paul once wrote that, thanks to the immortality and incorruptibility granted to believers by Christ, "Death is swallowed up in victory. O death, where is thy sting? O grave, where is thy victory" (I Cor. 15:54-5). So, too, do Early Modern writers recognize a power even higher than Mortality, that of the Divine. In the Early Modern mind, this Divine God not only loves His creations, but He is in love with them in an almost pagan fashion. Thus, death, which is a site of transformation from finitude into infinitude, is a marriage elevating the mortal bride to the plane of the immortal bridegroom. In the Early Modern Period, Death is the meeting point between mortal life in the form of orgasmic energy and the religious ecstasy of total devotion to God. Death is a consummation devoutly to be wished, not, as Hamlet would have it, because of the end of tiresome life, but because it is the completion of the mortal's relationship with the Divine. 


\section{REFERENCES}

Apuleius. The Transformations of Lucius, Otherwise Known as the Golden Ass. Trans. Robert Graves. New York: Farrar, Straus \& Giroux, 1951. Print.

Aristotle. Poetics. The Loeb Classical Library. 2nd ed. Trans. Stephen Halliwell. Cambridge: Harvard UP, 1995. 28-141. Print.

Baldung Grien, Hans. Death and the Maiden. National Gallery of Art, Washington, D.C. Artnet.com. Web. 22 Mar. 2013.

---. Death and the Maiden. Kunstmuseum, Basel. Wikipedia.com. Web. 22 Mar. 2013.

---. Hans Baldung Grien: Prints and Drawings: National Gallery of Art, Washington, from January 25 through April 5 and Yale University Art Gallery, New Haven, April 23 through June 14, 1981: Exhibition. Ed. James H. Marrow and Alan Shestack. New Haven: Yale University Art Gallery, 1981. Print.

---. Three Ages of Woman and Death. Kunsthistorisches Museum, Vienna. Wikipedia.com. Web. 22 Mar. 2013.

Bernini, Gian Lorenzo. The Ecstasy of St. Teresa. Santa Maria della Vittoria, Rome. Smart History. Khan Academy. Web. 8 Dec. 2011.

---. Details of the Ecstasy of St. Teresa. Santa Maria della Vittoria, Rome. Jahsonic.tumblr.com. Web. 8 Dec. 2011.

The Bible: Authorized King James Version. Oxford: Oxford UP, 2008. Print.

Binski, Paul. Medieval Death: Ritual and Representation. Ithaca: Cornell UP, 1996. Print.

Bynum, Caroline Walker. "Death and Resurrection in the Middle Ages: Some Modern Implications." Proceedings of the American Philosophical Society. 142.4: 1998, 589-596. Print.

Cabanel, Alexandre. Ophelia. Private Collection. Wikipedia.com. Web. 9 Dec. 2011.

Coles, Andrew. "Biomedical Models of Reproduction in the Fifth Century and Aristotle's Generation of Animals.” Phronesis. 40.1: 1995, 48-88. Print. 
Donne, John. "The Apparition." John Donne's Poetry: A Norton Critical Edition. Ed. Donald R. Dickson. New York: W.W. Norton \& Company, 2007. 69. Print.

---. "Batter my heart, three-person'd God." John Donne's Poetry. Ed. Donald R. Dickson. New York: W.W. Norton \& Company, 2007. 140. Print.

---. "Since she whom I loved hath paid her last debt." John Donne's Poetry. Ed. Donald R. Dickson. New York: W.W. Norton \& Company, 2007. 143-4. Print.

---. "The Relic." John Donne's Poetry: A Norton Critical Edition. Ed. Donald R. Dickson. New York: W.W. Norton \& Company, 2007. 110-111. Print.

Dowden, Ken. "Origins of Mythology: a View from the Grave." Death and the Maiden: Girls' Initiation Rites in Greek Mythology. New York: Routledge, 1989. 1-8. Print.

Foucault, Michel. The History of Sexuality, Volume I: An Introduction. Trans. Robert Hurley. New York: Random House, 1990. Print.

---. The Use of Pleasure: Volume 2 of the History of Sexuality. Trans. Robert Hurley. New York: Pantheon Books, 1985. Print.

Fulgentius, Fabius Planciades. "The Mythologies." The Mythographer. Trans. Leslie George Whitehead. Columbus: Ohio State UP, 1971. Print.

Guibbory, Achsah. "Erotic Poetry." The Cambridge Companion to John Donne. Ed. Achsah Guibbory. Cambridge: Cambridge UP, 2006. 133-47. Print.

---. "The Gospel According to Aemilia." Aemilia Lanyer: Gender, Genre, and Canon. Ed. Marshall Grossman. Lexington: UP of Kentucky, 1998. 191-211. Print.

Hodgson, John A. "Desdemona's Handkerchief as an Emblem of Her Reputation.” Texas Studies in Literature and Language. 19.3 (1977): 313-22. Print.

Holbein, Hans the Younger. Dance of Death. Ca. 1522-1526. "Medieval Macabre: The Hans Holbein Dance of Death." Web. 5 Dec. 2011.

Huskinson, Janet. Roman Children's Sarcophagi: Their Decoration and Its Social Significance. Oxford: Clarendon Press, 1996. Print.

Julian of Norwich. "Chapter 3 of A Book of Showings to the Anchoress Julian of Norwich." The Norton Anthology of English Literature. 9th ed. Vol. A. Ed. Stephen Greenblatt, et al. New York: W.W. Norton \& Company, 2012. 414-5. Print. 
Kempe, Margery. "Book 1 of The Book of Margery Kempe." The Norton Anthology of English Literature. 9th ed. Vol. A. Ed. Stephen Greenblatt, et al. New York: W.W. Norton \& Company, 2012. 425-38. Print.

Kurtz, Leonard P. The Dance of Death and the Macabre Spirit in European Literature. New York: Institute of French Studies, Inc.,1934. Print.

Lanyer, Aemilia. "Salve Deus Rex Judaeorum." The Poems of Aemilia Lanyer. Ed. Susanne Woods. Oxford: Oxford UP, 1993. 51-138. Print.

---. "To all vertuous Ladies in generall." The Poems of Aemilia Lanyer. Ed. Susanne Woods. Oxford: Oxford UP, 1993. 12-16. Print.

---. "To the Ladie Susan, Countesse Dowager of Kent, and Daughter to the Duchesse of Suffolke." The Poems of Aemilia Lanyer. Ed. Susanne Woods. Oxford: Oxford UP, 1993. 18-20. Print.

Manuel, Niklaus. Bern Dance of Death. Bern Münster, Bern. Arts \& Humanities Research Council. Web. 8 Dec. 2011.

Millais, Sir John Everett. Ophelia. Tate Britain, London. Tate.org. Web. 10 Dec. 2011.

Naso, Ovidius. Shakespeare's Ovid: The Metamorphoses. Trans. Arthur Golding. Ed. W.H.D. Rouse. New York: W.W. Norton \& Company, 1966. Print.

Neumann, Erich. Amor and Psyche: The Psychic Development of the Feminine. Trans. Ralph Manheim. New York: Princeton UP, 1956. Print.

OED. “Angel, n.1." Oxford English Dictionary Online. 2nd ed. Oxford UP, 2000. Web. 26 Mar. 2013

---. "Consummation, n." Oxford English Dictionary Online. 2nd. ed. Oxford UP, 2000. Web. 4 Dec. 2011.

---. "Lay, v.1" Oxford English Dictionary Online. 2nd. ed. Oxford UP, 2000. Web. 17 Nov. 2011.

---. "Maidenhead, n.1." Oxford English Dictionary Online. 2nd ed. Oxford UP, 2000. Web. 22 Oct. 2011.

---. “Paramour, n. 3." Oxford English Dictionary Online. 2nd ed. Oxford UP, 2000. Web. 26 Mar. 2013

---. “Woman, n. 6." Oxford English Dictionary Online. 2nd ed. Oxford UP, 2000. Web. 22 Oct. 2011. 
Ralegh, Walter. "Methought I saw the grave where Laura lay." The Norton Anthology of English Literature. 8th ed. Vol. 1. Ed. Stephen Greenblatt, et al. New York: W.W. Norton \& Company, 2006. 921-2. Print.

Rambuss, Richard. “Christ's Ganymede.” Closet Devotions. Durham: Duke UP, 1998. Print.

Sarcophagus. $3^{\text {rd }}$ century A.D. The British Museum, London. The British Museum. Web. 23 Feb. 2013.

Sarcophagus Panel: Cupid and Psyche. $4^{\text {th }}$ century A.D. Indianapolis Museum of Art, Indianapolis. Indianapolis Museum of Art. Web. 23 Feb. 2013.

Schwartz, Howard. "The Finger." Leaves from the Garden of Eden: One Hundred Classic Jewish Tales. Oxford: Oxford UP, 2009. 227-9. Print,

Shakespeare, William. Hamlet: A Norton Critical Edition. 3rd ed. Ed. Robert S. Miola. New York: W.W. Norton \& Company, 2011. 1-130. Print.

---. Macbeth. The Norton Shakespeare. 2nd ed. Ed. Stephen Greenblatt, et al. New York: W.W. Norton \& Company, 2008. 2569-632. Print.

---. Othello. The Norton Shakespeare. 2nd ed. Ed. Stephen Greenblatt, et al. New York: W.W. Norton \& Company, 2008. 2109-261. Print.

---. Romeo and Juliet. The Norton Shakespeare. 2nd ed. Ed. Stephen Greenblatt, et al. New York: W.W. Norton \& Company, 2008. 897-972. Print.

---. "Sonnet 130." The Norton Shakespeare. 2nd ed. Ed. Stephen Greenblatt, et al. New York: W.W. Norton \& Company, 2008. 1990. Print.

Spenser, Edmund. "Sonnet 64." The Norton Anthology of English Literature. 9th ed. Vol. B. Ed. Stephen Greenblatt, et al. New York: W.W. Norton \& Company, 2012. 987. Print.

Surrey, Henry Howard Earl of. "Wyatt resteth here that quick could never rest." The Norton Anthology of English Literature. 8th ed. Vol. 1. Ed. Stephen Greenblatt, et al. New York: W.W. Norton \& Company, 2006. 612-3. Print.

Targoff, Ramie. "Introduction." John Donne, Body and Soul. Chicago: U of Chicago P, 2008. Print.

Teresa of Ávila, Saint. The Life of Saint Teresa of Ávila by Herself. Trans. J.M. Cohen. New York: Penguin Books, 1957. Print. 
Torel, William. Copy of Effigy on the tomb of Eleanor of Castile. V\&A Museum Collection. Web. 9 Dec. 2011.

Webster, John. The Duchess of Malfi. The Norton Anthology of English Literature. $9^{\text {th }}$ ed. Vol. B. Ed. Stephen Greenblatt, et al. New York: W.W. Norton \& Company, 2012. 1572-1647. Print.

Wells, Robin Headlam. "Neo-Petrarchan Kitsch in 'Romeo and Juliet." Modern Language Review. 93.4 (1998): 913-33. Print. 


\title{
CURRICULUM VITAE
}

\author{
Whitney L. Brown
}

whitneylbrown2011@gmail.com

\section{EDUCATION}

B.A., English and the Dramatic Arts

Centre College, 2007-2011

University of Louisville

\section{EMPLOYMENT}

- $\quad$ Spring 2013 - English 102: Intermediate College Writing

- Fall 2012 - English 101: Introduction to College Writing

- Spring 2012 - Writing Center Consultant

- Fall 2011 - Writing Center Consultant

Centre College

- $\quad$ Spring 2011 - Writing Center Consultant

- Fall 2010 - Writing Center Consultant

\section{AWARDS}

- Recipient, University of Louisville English Graduate Teaching Assistantship

- Member, Centre College's Dean's List

- Recipient, John W. Redd English Prize

- Brown Scholar

- Centre College Fine Arts Scholarship for Music and Dramatic Arts

- Governor's Scholar

\section{SOCIETIES}

- Phi Beta Kappa Honor Society

- Omicron Delta Kappa Honor Society

\section{PRESENTATIONS}

- 2012 National Conference on Peer Tutoring in Writing - Chicago, IL

- 2012 University of Louisville Graduate Research Symposium - Louisville, KY

- 2011 RICE Symposium - Danville, KY

- $\quad$ The Tudor Women, an original one-act play - Danville, KY

- "First Claims," an original ten-minute play - Danville, KY 